\title{
EFFECTS OF CADMIUM EXPOSURE ON PROXIMATE ANALYSIS AND METALLIC ELEMENT CONTENTS OF WEDGE CLAM (DONAX TRUNCULUS)
}

\author{
KroINI, H. ${ }^{1}-$ HAMdANI, A. ${ }^{*}-$ SOlTANI, N. ${ }^{1}-$ ZAIDI, N. ${ }^{2}-$ SLEIMI, N. ${ }^{3}$ \\ ${ }^{1}$ Laboratory of Applied Animal Biology, Faculty of Sciences, Department of Biology, Badji \\ Mokhtar University, 23000 Annaba, Algeria \\ ${ }^{2}$ Laboratory for the Optimization of Agricultural in Subhumid Areas, Department of Natural \\ and Life Sciences, Faculty of Sciences, University of Skikda, 21000 Skikda, Algeria \\ ${ }^{3}$ Laboratory RME-Resources, Materials and Ecosystems, Faculty of Sciences of Bizerte, \\ University of Carthage, Carthage, Tunisia \\ *Corresponding author \\ e-mail: a_hamdaniamel@yahoo.fr; phone: +213-55-786-3661 \\ (Received $6^{\text {th }}$ Aug 2021; accepted $28^{\text {th }}$ Oct 2021)
}

\begin{abstract}
The present study was designed to investigate the proximate (moisture, dry matter, ash, and fat content) composition and metallic element contents $(\mathrm{Ca}, \mathrm{Zn}, \mathrm{Fe}$, and $\mathrm{Cd})$ in an edible Bivalve, Donax trunculus from the gulf of Annaba, and to evaluate the effect of cadmium (Cd) on these parameters. The clams were collected from the El-Battah site during the morphologically ripe and reared stages under laboratory conditions. Physicochemical parameters of seawater samples including temperature, $\mathrm{pH}$, salinity, and dissolved oxygen were determined. Cadmium at two sub-lethal concentrations $\left(\mathrm{LC}_{10}\right.$ and $\mathrm{LC}_{25}-96 \mathrm{~h}$ as determined previously) was added to the rearing water. The results revealed significant effects of $\mathrm{Cd}$ concentrations, exposure time, and sex on all the studied parameters. Indeed, the contents of dry matter, fat and metallic elements, excluding $\mathrm{Cd}$ were significantly decreased, while the moisture, ash, and $\mathrm{Cd}$ contents were significantly increased in both sexes at two sub-lethal concentrations. Moreover, the measurement of proximate composition and minerals contents in $D$. trunculus could be a very useful approach to evaluate the nutritive value changes in case of exposure to cadmium contamination, and subsequently to avoid health-associated problems.
\end{abstract}

Keywords: pollution, mollusk, heavy metals, acute toxicity, bioindicator, seafood, nutritive value

\section{Introduction}

Heavy metals are one of the major persistent wastewater pollutants, nonbiodegradable and naturally toxic within a short period (Zhang et al., 2016). Recently, a great concern has been raised for the impact of heavy metals on the environment (Bankaji et al., 2019; Sall et al., 2020; Sleimi et al., 2021). Indeed, marine ecosystems are vulnerable to trace element contamination posing a considerable hazard to the environment and human health (Dhinamala et al., 2017; Obaiah et al., 2020). Most seafood products, including Mollusk Bivalves are considered biological indicators of heavy metal pollution through the food web (Tulonenet al., 2006; Vieira et al., 2021). Overall, these mollusks are excellent sources of nutrients due to their high-value in protein contents, low-fat contents and marked contents in essential micronutrients (e.g., vitamins D, A and B, water, and minerals) (Orban et al., 2002; Gil and Gil, 2015; Wright et al., 2018). Further, the proximate composition is a valuable tool to identify the quality of meat and to understand the nutritive value changes (Margret, 2015; Ogidi et al., 2020). Besides, some metals like calcium (Ca), Zinc ( $\mathrm{Zn})$, iron (Fe) required in 
minute quantities for the organisms' metabolism and growth are referred to as essential metallic elements (Yusoff and Long, 2011; Hossen et al., 2015). These essential metallic elements are important components for hormones, activators of enzymes, and are effectively involved in various oxidation-reduction reactions (Khan, 1992; Wright et al., 2018), and the process of muscle contraction, nerve conductance, and energy production (Margret et al., 2013). In addition, these metallic elements (ME) become toxic to organisms at concentrations exceeding the recommended limits (Beldi et al., 2006), meanwhile certain other metallic elements like $\mathrm{Cd}$ are not essential for any biological process in the organism, and become toxic even at low concentrations (Astudillo et al., 2005). According to the United States, Environmental Protection Agency (U.S. EPA), and the International Agency for Research on Cancer (IARC), Cd ranks among the highly hazardous metals for the public health. Also, it is reported to induce the generation of free radicals causing chronic oxidative kidney damages and cancers (Salama and Radwan, 2005; Obaiah, 2020). In this context, the assessment of trace element contents in seafood is an important step in ensuring food safety for the sake of human health.

Donax trunculus, an edible Mollusk Bivalve, is a suitable species for the aquatic environment biomonitoring, and also successfully used as a bioindicator to monitor seawater quality worldwide (Künili et al., 2020; Costa et al., 2021; Patino et al., 2021). This wedge clam is chosen as sentinel species due to their typical properties, including life traits, wide geographical distribution, suitable size, facility of collection, transplantation and maintenance in the laboratory, in addition to their ability to concentrate pollutants (Tlili and Mouneyrac, 2019; Hamdani et al., 2020). In the gulf of Annaba (Northeast Algeria), D. trunculus is the most widely distributed bivalve in sand beaches (Beldi et al., 2006; Hafsaoui et al., 2016), and the most consumed by the local population (Merad et al., 2017). Thus, D. trunculus can be mainly targeted by several environmental pollutants from different sources including heavy metals, in particular, Cd that has been found in tissues of D. trunculus and sediments (Beldi et al., 2006; Drif et al., 2010; Amira et al., 2018). The research investigating the sub-lethal Cd exposure was performed in order to understand the toxic effects other than lethal effects, which are usually expressed by the real environmental pollution states (Mouabad, 1991; Dutta et al., 2017).

Previous studies conducted in the gulf of Annaba have investigated the sub-lethal toxic effects of $\mathrm{LC}_{10}$ and $\mathrm{LC}_{25}-96 \mathrm{~h}$ of $\mathrm{Cd}$ on D. trunculus on the contents of metallothioneins (Mts) (Merad et al., 2015; Rabei et al., 2018), protein carbonyls (Pc) (Merad et al., 2016), omega-3 fatty acids (Merad et al., 2017) and nucleic acid (Merad and Soltani, 2015), and the biochemical components of gonads (Merad and Soltani, 2017). So, the essential previous results showed a significant reduction in the main essential omega-3 fatty acid (EPA and DHA concentrations), in the level of $A R N$, in the level of biochemical composition. A significant elevation in the Pc level and MTS level was also detected. The current study, is in continuation to previous studies, was undertaken to assess the sub-lethal $\mathrm{Cd}$ exposure $\left(\mathrm{LC}_{10}\right.$ and $\mathrm{LC}_{25}-96 \mathrm{~h}$ ) on the proximate composition and minerals contents of $D$. trunculus females and males in order to compare the data obtain with previous reports we have chosen to test similar sublethal concentrations. Noteworthy, the nutritive value, considered as an important index for determining the quality of meat and the understanding of the nutritive value changes under metallic contamination, has not been examined until now in the gulf of Annaba. 


\section{Review of literature}

Our results are original data for proximate composition and minerals contents of an edible mollusk bivalve D. trunculus from gulf of Annaba (Algeria). Also, it is the first study to elucidate the toxicity of $\mathrm{Cd}$ on proximate and essential metallic elements of $D$. trunculus.

\section{Materials and methods}

\section{Animal collection and treatment with sub-lethal concentrations of cadmium}

The experiments were performed in March 2019 where the majority of individuals were in the stage of morphologically ripe (Hamdani et al., 2020), and all individuals tested were in the morphologically ripe. The Gulf of Annaba city (northeast Algeria) is surrounded from the East by the Cap Rosa $\left(8^{\circ} 15^{\prime} \mathrm{E}\right.$ and $\left.36^{\circ} 38^{\prime} \mathrm{N}\right)$, and from the West by the Cap Garde $\left(7^{\circ} 16^{\prime} \mathrm{E}\right.$ and $\left.36^{\circ} 68^{\prime} \mathrm{N}\right)$. D. trunculus samples were collected from $\mathrm{El}$ Battah beach ( $\left.36^{\circ} 50^{\prime} \mathrm{N}-7^{\circ} 50^{\prime} \mathrm{E}\right)$ located approximately $30 \mathrm{~km}$ East from Annaba city, and precisely in the eastern area close to the Mafragh estuary characterized by low levels of all nutrients (Ounissi et al., 2014). El Battah site, distant site from any anthropogenic pressures, is subjected to an important hydrodynamic regime, likely contributing to the pollutants dilution (Rabei et al., 2018) (Fig. 1). Of note, the suspension feeder bivalve $D$. trunculus is preferentially present between 0 and $2 \mathrm{~m}$ in depth in the Mediterranean Sea (Gaspar et al., 2002; La Valle, 2006; Tlili and Mouneyrac, 2019), and hence samples were collected by a hand rake as described elsewhere (Hafsaoui et al., 2016). The experimental animals were brought to the laboratory and macroscopically separated by sex based on the color of gonads (dark blue gonads indicate females, and the yellow-white ones indicate males) according to Gaspar (1999). Further, the rearing was conducted in aquaria taken from the sandy and seawater of the sampling area. During all the experiments, the water was constantly aerated with air pumps (Nirox X5) and photoperiod approximately $12 \mathrm{~h}$ dark and $12 \mathrm{~h}$ light. Adults $D$. trunculus were acclimatized for $48 \mathrm{~h}$ in filtered seawater before the experimental procedures (Belabed and Soltani, 2013). The physicochemical parameters of seawater measured by a multi-parameter water analyzer (Multi $340 \mathrm{i}$, Germany) were temperature $\left(16.21 \pm 0.5{ }^{\circ} \mathrm{C}\right)$, salinity $(32.6 \pm 1.5 \mathrm{~g} / \mathrm{l}), \mathrm{pH}(8.10 \pm 0.1)$, and dissolved oxygen $(8.20 \pm 1.2 \mathrm{mg} / \mathrm{l})$. After the laboratory acclimation period, the aquariums containing D. trunculus were separated into control and experimental groups (Fig. 2). The sub-lethal acute exposure to cadmium chloride $\left(\mathrm{CdCl}_{2}\right.$ : Sigma, USA) as a commercial form of cadmium was performed according to preliminary bioassay applied on D. trunculus as previously reported (Merad and Soltani, 2015). Here, D. trunculus females and males were exposed to two sub-lethal concentrations ( $\mathrm{LC}_{10}$ and $\left.\mathrm{LC}_{25}\right)$ of cadmium chloride $\left(\mathrm{CdCl}_{2}\right)$ for $96 \mathrm{~h}$ for each sex (females: $\mathrm{LC}_{10}(0.94 \mathrm{mg} / \mathrm{l})$ and $\mathrm{LC}_{25}$ $(1.6 \mathrm{mg} / \mathrm{l})$; males: $\mathrm{LC}_{10}(1.15 \mathrm{mg} / \mathrm{l})$ and $\mathrm{LC}_{25}(2.02 \mathrm{mg} / \mathrm{l})$ (Merad and Soltani, 2015; Merad et al., 2017). D. trunculus were fed every day with a commercial food mixture (Marine Invertebrate Diet. Carolina Ltd., NC, and USA). Animals were dissected at various point times $(0,48$ and $96 \mathrm{~h})$ to remove their soft tissues.

\section{Proximate composition determination}

The soft tissues of four individuals of $D$. trunculus per treatment were used each $48 \mathrm{~h}$, and the basic proximate composition of D. trunculus (moisture, dry matter, ash, 
and fat) was determined according to the Association of Official Analytical Chemists methods (AOAC, 2000). All measured values were presented in percentages.

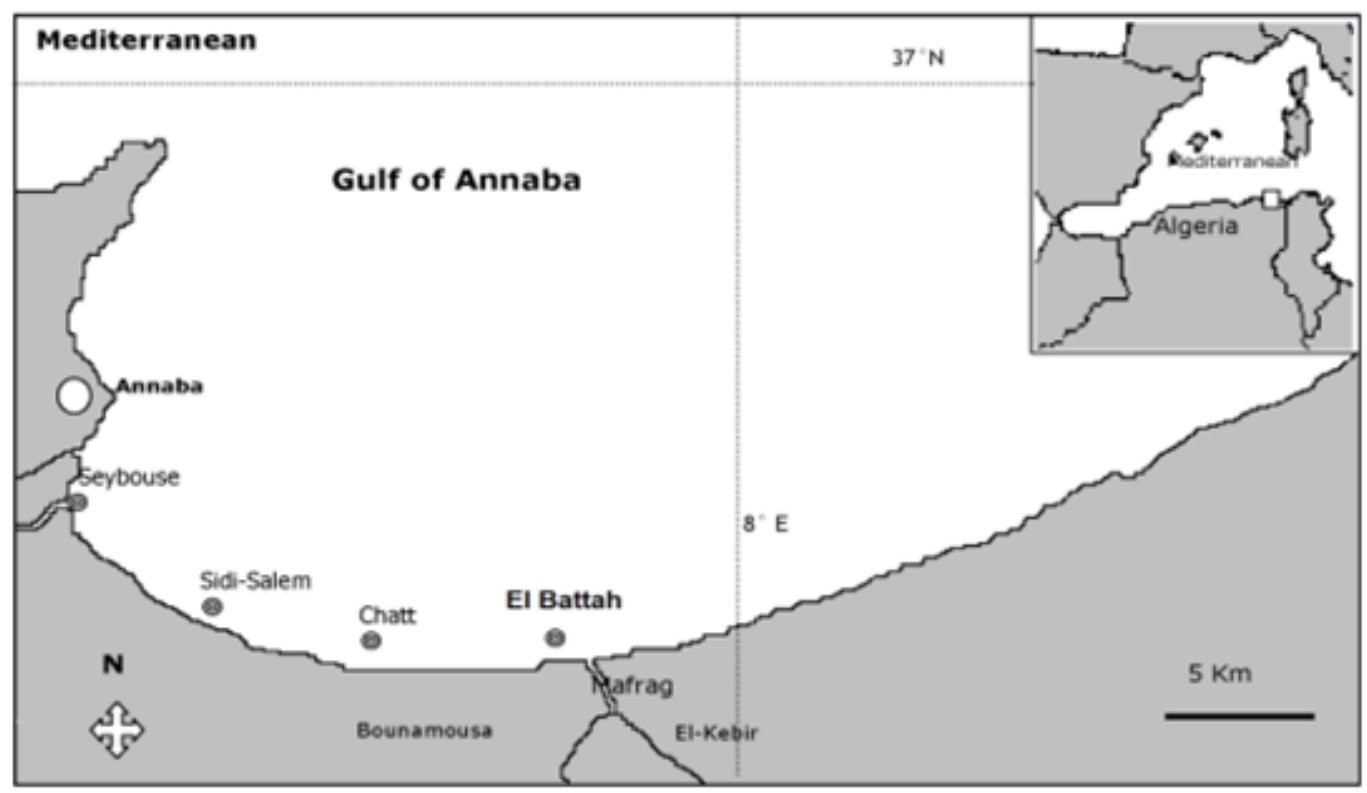

Figure1. Location of El Battah site in the Gulf of Annaba (Northeast Algeria)

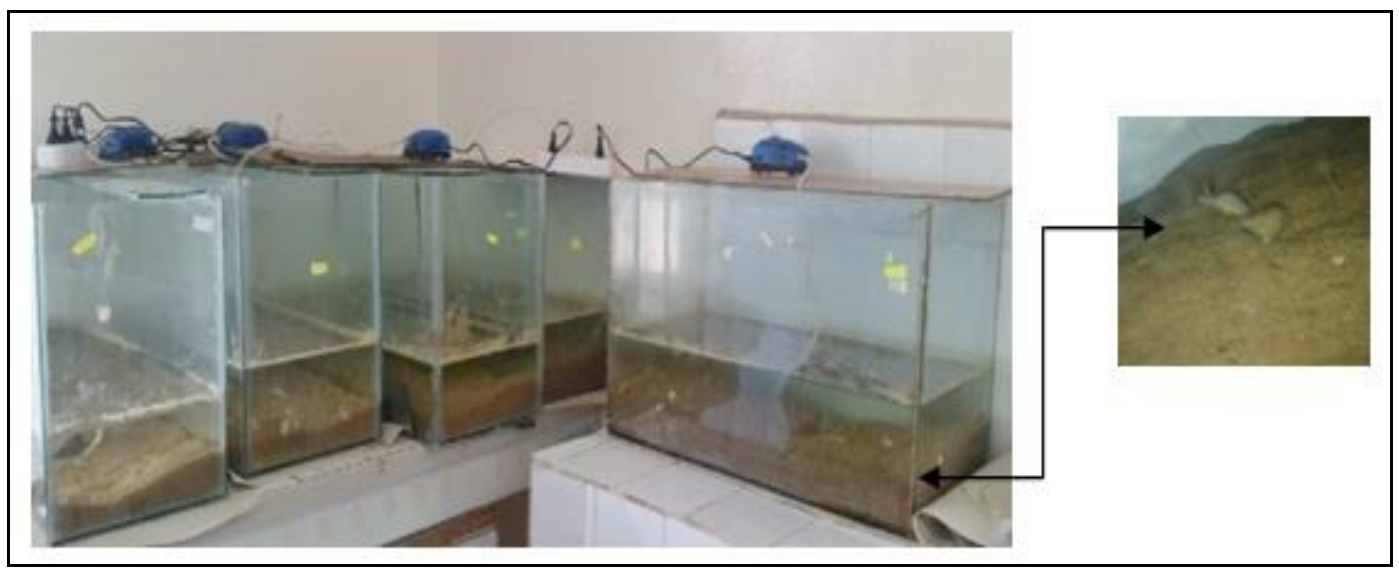

Figure2. Experimental culture of D. trunculus in the laboratory

\section{Moisture and dry matter determination}

Moisture defined as the main component of the feed nutrient or ingredients was determined from the weight difference before and after drying the samples at $105^{\circ} \mathrm{C}$ overnight to constant weight (Bhobe and Pai, 1986) according to the following formula (Eq. 1):

$$
\% \text { moisture content }=\frac{\mathrm{M} 1}{\mathrm{M} 2} \times 100
$$

where M1 is the weight sample loss (grams); M2 is the mass of the used sample (grams). 
The percentage of dry matter content in the sample was calculated by the following formula (Eq. 2):

$\%$ Dry matter content $=100 \%-$ moisture content

\section{Ash content determination}

Ash content, the residues of the inorganic matter (mineral) of the sample after burning, was estimated after incinerating the sample in a muffle furnace at $550{ }^{\circ} \mathrm{C}$ for $12 \mathrm{~h}$ until constant weight as described by AOAC method 920.153 (Eq. 3):

$$
\% \text { Ash content }=\frac{\mathrm{M} 1}{\mathrm{M} 2} \times 100
$$

where M1 is the weight of ash (grams); and M2 is the weight of the used sample (grams).

\section{Fat content determination}

Fat content in D. trunculus sample determined by Soxhlet method contains only free lipids, but not all lipid forms (Larpent, 1997). The Soxhlet extraction experiment was performed with a Franz Von Soxhlet according to AOAC method 960.39 using petroleum ether as solvent. In brief, $10 \mathrm{~g}$ of samples were included in a cartridge to enable to proceed the extraction procedure for $5 \mathrm{~h}$. After the subsequent extraction, the residual solvent evaporates, and the results fall in the round bottom flask which was thereafter, heated in an oven to achieve permanent weight and then cooled in a desiccator. Fat content was measured and expressed as percent by weight as follows (Eq. 4):

$$
\% \text { Fat content }=\frac{\mathrm{g} \text { fat of sample }}{\mathrm{g} \text { weight of sample }} \times 100
$$

\section{Determination of metallic elements}

Three pool replicates of three individuals of $D$. trunculus per treatment were used each $48 \mathrm{~h}$; the contents of $\mathrm{Cd}, \mathrm{Ca}, \mathrm{Fe}$, and $\mathrm{Zn}$ were measured by atomic absorption spectrometry using a Perkin Elmer 900T instrument (Perkin Elmer PinAAcle 900T, USA). In brief, as previously described by Bryan et al. (1977), the soft tissues were dried at $110{ }^{\circ} \mathrm{C}$ to a constant weight, homogenized and crushed in a mortar to obtain a fine powder which afterward was kept away from metallic materials to avoid contamination until analyze. Thereafter, $0.20 \mathrm{~g}$ of dry sample was mineralized with muffle furnace at $350{ }^{\circ} \mathrm{C}$ to $450{ }^{\circ} \mathrm{C}$, and two milliliters of nitric acid were added. After evaporation, ashes were cooled and the resulting residue was dissolved in $25 \mathrm{ml}$ of nitric acid $1 \%$, and filtered through a filter paper (Whatman $\mathrm{N}^{\circ} 1$ ). The filtered sample was aspirated into the atomic absorption spectrophotometer at mode flame, and the reading was registered. The blank was used to adjust the zero of the instrument and to detect possible cross-contamination. All reagents were obtained from Merck and were of analytical grade. Metallic element contents were expressed in $\mu \mathrm{g} / \mathrm{g}$ of dry weight $(\mathrm{dw})$.

\section{Statistical analyses}

Data are expressed as mean \pm standard deviation (SD). Statistical analyses were performed using the MINITAB Software (Version 17, Penn State College, PA, USA) 
where $\mathrm{p}<0.05$ was considered statistically significant. The normality was tested by the Kolmogorov-Smirnov test, and the homogeneity of variances was checked by Levine's test. One-way analysis of variance (ANOVA) followed by Tukey's post-hoc test was used to evaluate the difference between treatment means. The effects of concentrations, exposure time, and sex were tested by a three-way analysis of variance (ANOVA). The correlation between all parameters was examined by the Pearson correlation test $(\mathrm{R}=$ coefficient of correlation, $\mathrm{p}$-value of correlation $=$ significance at $\mathrm{p}<0.05)$.

\section{Results}

\section{Effects of sub-lethal concentrations of cadmium on the proximate composition}

Tables 1 and 2 showed the effect of $\mathrm{Cd}$ on proximate composition in females and males of $D$. trunculus respectively. The proximate composition varies as a function of cadmium concentration and exposure time, and sex.

\section{Sub-lethal effects of Cd on the percentage of moisture contents}

As shown in Tables 1 and 2, a significant increase in moisture contents was observed in the two treated series as compared to control series in both sexes. Also, there was a significant difference in the $\mathrm{LC}_{10}$ and $\mathrm{LC}_{25}$-treated series at $48 \mathrm{~h}\left(\mathrm{~F}_{2} .11=9.34\right.$; $\mathrm{p}=0.006)$ and $96 \mathrm{~h}\left(\mathrm{~F}_{2.11}=48.17 ; \mathrm{p}=0.000\right)$ as compared to control series $(0 \mathrm{~h})$ in females (Table 1; Tables A1 and A2 in the Appendix). The males presented a significant difference in the two treated series at $48 \mathrm{~h}\left(\mathrm{~F}_{2.11}=6.45 ; \mathrm{p}=0.018\right)$ and $96 \mathrm{~h}\left(\mathrm{~F}_{2}\right.$. $11=26.58 ; \mathrm{p}=0.000)$ as compared to control series (Tables 2, A3 and A4). The threeway ANOVA indicated significant effects of concentrations $\left(F_{2.71}=49.05 ; \mathrm{p}=0.000\right)$, exposure time $\left(\mathrm{F}_{2.71}=63.96 ; \mathrm{p}=0.000\right)$ and $\operatorname{sex}\left(\mathrm{F}_{1.71}=73.16 ; \mathrm{p}=0.000\right)($ Table A5).

\section{Sub-lethal effects of cadmium on the percentage of dry matter contents}

As indicated in Tables 1 and 2, a significant decrease in the percentage of dry matter contents was detected in the two tested concentrations as compared to control groups in both sexes. The dry matter contents differed significantly in the two tested concentrations at $48 \mathrm{~h}\left(\mathrm{~F}_{2.11}=9.34 ; \mathrm{p}=0.006\right)$ and $96 \mathrm{~h}\left(\mathrm{~F}_{2.11}=44.24 ; \mathrm{p}=0.000\right)$ as compared to control in females (Tables 1, A6 and A7). Meanwhile, this parameter differed significantly in the two treated series at $48 \mathrm{~h}\left(\mathrm{~F}_{2 .}{ }_{11}=6.45 ; \mathrm{p}=0.018\right)$ and $96 \mathrm{~h}\left(\mathrm{~F}_{2 .} .11=26.58\right.$; $\mathrm{p}=0.000$ ) as compared to control in males (Tables 2, A8 and A9). The three-way ANOVA showed significant effects of concentration $\left(F_{2.71}=47.36 ; p=0.000\right)$, exposure time $\left(\mathrm{F}_{2.71}=61.59 ; \mathrm{p}=0.000\right)$, and $\operatorname{sex}\left(\mathrm{F}_{1.71}=72.83 ; \mathrm{p}=0.000\right)($ Table A10 $)$.

\section{Sub-lethal effects of cadmium on the percentage of ash contents}

As presented in Table 1 and 2, the percentage of ash contents was significantly increased in the two treated series when compared with control series of both sexes. This parameter differs significantly in the $\mathrm{LC}_{10}$ and $\mathrm{LC}_{25}$-treated series at $48 \mathrm{~h}\left(\mathrm{~F}_{2}\right.$. $11=19.82 ; \mathrm{p}=0.001)$ and $96 \mathrm{~h}\left(\mathrm{~F}_{2.11}=34.57 ; \mathrm{p}=0.000\right)$ as compared to control in females, with marked effect in $\mathrm{Cl}_{25}$ treated series (Tables 1, A11 and A12). Similarly, males showed a significant difference in ash contents in the two treated series at $48 \mathrm{~h}$ $\left(\mathrm{F}_{2.11}=19.62 ; \mathrm{p}=0.001\right)$ and $96 \mathrm{~h}\left(\mathrm{~F}_{2.11}=32.64 ; \mathrm{p}=0.000\right)$ as compared to control, with pronounced effect in $\mathrm{Cl}_{25}$ treated series (Tables 2, A13 and A14). The three-way 
ANOVA revealed significant effects of concentrations $\left(\mathrm{F}_{2.71}=60.98 ; \mathrm{p}=0.000\right)$ and exposure time $\left(\mathrm{F}_{2.71}=70.50 ; \mathrm{p}=0.000\right)$, and $\operatorname{sex}\left(\mathrm{F}_{1.71}=66.38 ; \mathrm{p}=0.000\right)($ Table A15).

Table 1. Effect of Cd on proximate composition (\%) in D. trunculus females $(m \pm S D . n=4)$. (Means for the same time exposure (the rows) followed by the different letter in miniscule are significantly different, while for each treatment (the columns), values followed by the different letter in majuscule are significantly different at $p \leq 0.05$ )

\begin{tabular}{c|c|c|c|c}
\hline \multirow{2}{*}{$\begin{array}{c}\text { Proximate } \\
\text { composition (\%) }\end{array}$} & \multirow{2}{*}{$\begin{array}{c}\text { Exposure time } \\
(\mathbf{h})\end{array}$} & $\mathbf{C o n t r o l}$ & $\mathbf{L C}_{\mathbf{1 0}}$ & $\mathbf{L C}_{\mathbf{2 5}}$ \\
\cline { 3 - 5 } & 0 & $77.21 \pm 1.11 \mathbf{a A}$ & $77.21 \pm 1.11 \mathbf{a A}$ & $77.21 \pm 1.11 \mathbf{a A}$ \\
\multirow{3}{*}{ Moisture content } & 48 & $77.39 \pm 0.97 \mathbf{a A}$ & $79.59 \pm 1.09 \mathbf{b B}$ & $80.56 \pm 1.12 \mathbf{b B}$ \\
& 96 & $77.61 \pm 0.81 \mathbf{a A}$ & $82.16 \pm 0.86 \mathbf{b C}$ & $82.49 \pm 0.66 \mathbf{b C}$ \\
\hline \multirow{3}{*}{ Dry matter } & 0 & $22.54 \pm 0.94 \mathbf{a A}$ & $22.54 \pm 0.94 \mathbf{a A}$ & $22.54 \pm 0.94 \mathbf{a A}$ \\
& 48 & $22.59 \pm 0.97 \mathbf{a A}$ & $20.40 \pm 1.09 \mathbf{b B}$ & $19.43 \pm 1.11 \mathbf{b B}$ \\
& 96 & $22.34 \pm 0.89 \mathbf{a A}$ & $17.82 \pm 0.86 \mathbf{b C}$ & $17.49 \pm 0.67 \mathbf{b C}$ \\
\hline \multirow{3}{*}{ Ash content } & 0 & $1.96 \pm 0.73 \mathbf{a A}$ & $1.96 \pm 0.73 \mathbf{a A}$ & $1.96 \pm 0.73 \mathbf{a A}$ \\
& 48 & $1.89 \pm 0.30 \mathbf{a A}$ & $3.03 \pm 0.40 \mathbf{b A B}$ & $4.12 \pm 0.64 \mathbf{c B}$ \\
& 96 & $2.33 \pm 0.12 \mathbf{a A}$ & $3.95 \pm 0.65 \mathbf{b B}$ & $4.89 \pm 0.37 \mathbf{c B}$ \\
\hline \multirow{2}{*}{ Fat content } & 0 & $1.82 \pm 0.05 \mathbf{a A}$ & $1.82 \pm 0.05 \mathbf{a A}$ & $1.82 \pm 0.05 \mathbf{~ a A}$ \\
& 48 & $1.77 \pm 0.07 \mathbf{a A}$ & $1.70 \pm 0.06 \mathbf{a B}$ & $1.53 \pm 0.08 \mathbf{b B}$ \\
& 96 & $1.75 \pm 0.06 \mathbf{a A}$ & $1.35 \pm 0.05 \mathbf{b C}$ & $1.20 \pm 0.05 \mathbf{c C}$ \\
\hline
\end{tabular}

Table 2. Effect of Cd on proximate composition (\%) in D. trunculus males ( $m \pm S D . n=4)$. (Means for the same time exposure (the rows) followed by the different letter in miniscule are significantly different, while for each treatment (the columns), values followed by the different letter in majuscule are significantly different at $p \leq 0.05$ )

\begin{tabular}{c|c|c|c|c}
\hline $\begin{array}{c}\text { Proximate } \\
\text { composition (\%) }\end{array}$ & $\begin{array}{c}\text { Exposure time } \\
(\mathbf{h})\end{array}$ & Control & $\mathbf{L C}_{\mathbf{1 0}}$ & $\mathbf{L C}_{\mathbf{2 5}}$ \\
\cline { 3 - 5 } & 0 & $75.44 \pm 0.91 \mathbf{a A}$ & $75.44 \pm 0.91 \mathbf{a A}$ & $75.44 \pm 0.91 \mathbf{a A}$ \\
\multirow{3}{*}{ Moisture content } & 48 & $75.35 \pm 0.84 \mathbf{a A}$ & $77.17 \pm 1.70 \mathbf{a b A}$ & $78.60 \pm 1.14 \mathbf{b B}$ \\
& 96 & $75.43 \pm 1.0 \mathbf{a A}$ & $80.28 \pm 1.2 \mathbf{b B}$ & $80.47 \pm 1.1 \mathbf{b B}$ \\
\hline \multirow{3}{*}{ Dry matter } & 0 & $24.56 \pm 0.91 \mathbf{a A}$ & $24.56 \pm 0.91 \mathbf{a A}$ & $24.56 \pm 0.91 \mathbf{a A}$ \\
& 48 & $24.64 \pm 0.84 \mathbf{a A}$ & $22.84 \pm 1.70 \mathbf{a b A}$ & $21.40 \pm 1.14 \mathbf{b B}$ \\
& 96 & $24.57 \pm 1.0 \mathbf{a A}$ & $19.72 \pm 1.20 \mathbf{b B}$ & $19.53 \pm 1.12 \mathbf{b B}$ \\
\hline \multirow{3}{*}{ Ash content } & 0 & $1.15 \pm 0.16 \mathbf{a A}$ & $1.15 \pm 0.16 \mathbf{a A}$ & $1.15 \pm 0.16 \mathbf{a A}$ \\
& 48 & $1.12 \pm 0.11 \mathbf{a A}$ & $2.03 \pm 0.49 \mathbf{b A B}$ & $3.09 \pm 0.58 \mathbf{c B}$ \\
& 96 & $1.35 \pm 0.06 \mathbf{a A}$ & $2.87 \pm 0.65 \mathbf{b B}$ & $3.82 \pm 0.38 \mathbf{c B}$ \\
\hline \multirow{3}{*}{ Fat content } & 0 & $1.31 \pm 0.04 \mathbf{a A}$ & $1.31 \pm 0.04 \mathbf{a A}$ & $1.31 \pm 0.04 \mathbf{a A}$ \\
& 48 & $1.27 \pm 0.05 \mathbf{a A}$ & $1.17 \pm 0.02 \mathbf{b B}$ & $1.08 \pm 0.03 \mathbf{c B}$ \\
& 96 & $1.24 \pm 0.03 \mathbf{a A}$ & $0.91 \pm 0.08 \mathbf{b C}$ & $0.56 \pm 0.08 \mathbf{c C}$ \\
\hline
\end{tabular}

\section{Sub-lethal effects of cadmium on the percentage of fat contents}

As given in Tables 1 and 2, the percentage of fat contents was significantly decreased in the two tested $\mathrm{Cd}$ concentrations as compared with those in controls of both sexes. 
Females exhibit a significant difference in this parameter in the $\mathrm{LC}_{10}$ and $\mathrm{LC}_{25}$-treated series at $48 \mathrm{~h}\left(\mathrm{~F}_{2.11}=11.37 ; \mathrm{p}=0.003\right)$ and $96 \mathrm{~h}\left(\mathrm{~F}_{2.11}=91.17 ; \mathrm{p}=0.000\right)$ as compared to control, with more effect in $\mathrm{Cl}_{25}$ treated series at $96 \mathrm{~h}$ (Tables 1, A16 and A17). Also, the fat contents differ significantly in males in the two treated series at $48 \mathrm{~h}\left(\mathrm{~F}_{2}\right.$. $\left.{ }_{11}=24.84 ; \mathrm{p}=0.000\right)$ and $96 \mathrm{~h}\left(\mathrm{~F}_{2.11}=83.33 ; \mathrm{p}=0.000\right)($ Tables 2, A18 and A19) as compared to control, with distinct effect in $\mathrm{Cl}_{25}$ treated series. The three-way ANOVA revealed significant effects of concentration $\left(\mathrm{F}_{2.71}=130.50 ; \mathrm{p}=0.000\right)$, and exposure time $\left(\mathrm{F}_{2.71}=277.73 ; \mathrm{p}=0.000\right)$ and $\operatorname{sex}\left(\mathrm{F}_{1.71}=1344.20 ; \mathrm{p}=0.000\right)($ Table A20 $)$.

\section{Effects of sub-lethal concentrations of cadmium on metallic element}

Tables 3 and 4 show the effect of $\mathrm{Cd}$ on $\mathrm{ME}$ in females and males of $D$. trunculus respectively. The ME contents vary as a function of cadmium concentration and exposure time, and sex.

\section{Calcium contents}

The Ca contents were significantly decreased in the two treated series as compared to control series in both sexes. A significant difference was observed in the level of this element in the $\mathrm{LC}_{10}$ and $\mathrm{LC}_{25}$-treated series at $48 \mathrm{~h}\left(\mathrm{~F}_{2.8}=49667.29 ; \mathrm{p}=0.000\right)$ and $96 \mathrm{~h}\left(\mathrm{~F}_{2.8}=13938.86 ; \mathrm{p}=0.000\right)$ as compared to control in females, with marked effect in $\mathrm{Cl}_{25}$ treated series (Tables 3, A21 and A22). Additionally, the Ca level element differed significantly in the two treated series at $48 \mathrm{~h}\left(\mathrm{~F}_{2.8}=823.03 ; \mathrm{p}=0.000\right)$ and $96 \mathrm{~h}\left(\mathrm{~F}_{2 .} .8=5624.86 ; \mathrm{p}=0.000\right)$ as compared to control in males, with pronounced effect in $\mathrm{Cl}_{25}$ treated series (Tables 4, A23 and A24). The three-way ANOVA showed significant effects of Cd concentrations $\left(\mathrm{F}_{2.53}=14560.76 ; \mathrm{p}=0.000\right)$, and exposure time $\left(\mathrm{F}_{2.53}=14597.25 ; \mathrm{p}=0.000\right)$ and $\operatorname{sex}\left(\mathrm{F}_{1.53}=79623.14 ; \mathrm{p}=0.000\right)($ Table A25)

\section{Iron contents}

The Fe contents in females and males of $D$. trunculus were significantly decreased in the two treated series as compared to control series in both sexes. There was a significant difference in the two tested concentrations at $48 \mathrm{~h}\left(\mathrm{~F}_{2.8}=182.74 ; \mathrm{p}=0.000\right)$ and $96 \mathrm{~h}\left(\mathrm{~F}_{2.8}=928.63 ; \mathrm{p}=0.000\right)$ as compared to control in females, with more effect in $\mathrm{Cl}_{25}$ treated series (Tables 3, A26 and A27). In parallel, D. trunculus males revealed a significant difference in $\mathrm{Fe}$ content in the two treated series at $48 \mathrm{~h}\left(\mathrm{~F}_{2.8}=7.42\right.$; $\mathrm{p}=0.024)$ and $96 \mathrm{~h}\left(\mathrm{~F}_{2.8}=100.77 ; \mathrm{p}=0.000\right)$ as compared to control, with remarkable effect in $\mathrm{Cl}_{25}$ treated series at $96 \mathrm{~h}$ (Tables 4, A28 and A29). The three-way ANOVA revealed significant effects of $\mathrm{Cd}$ concentration $\left(\mathrm{F}_{2.53}=325.15 ; \mathrm{p}=0.000\right)$ and exposure time $\left(\mathrm{F}_{2.53}=496.49 ; \mathrm{p}=0.000\right)$ and $\operatorname{sex}\left(\mathrm{F}_{1.53}=8324.47 ; \mathrm{p}=0.000\right)$ (Table A30).

\section{Zinc contents}

A significant decrease of $\mathrm{Zn}$ contents was observed in two groups of treated series as compared to control series in both sexes. In addition, the $\mathrm{Zn}$ contents were significantly differed in the $\mathrm{LC}_{10}$ and $\mathrm{LC}_{25}$-treated series at $48 \mathrm{~h}\left(\mathrm{~F}_{2.8}=954.29 ; \mathrm{p}=0.000\right)$ and $96 \mathrm{~h}$ $\left(\mathrm{F}_{2.8}=1636.34 ; \mathrm{p}=0.000\right)$ as compared to control in D. trunculus females, with distinct effect in $\mathrm{Cl}_{25}$ treated series (Tables 3, A31 and A32). In D. trunculus males (Tables 4, $A 33$ and $A 34)$, the $\mathrm{Zn}$ contents revealed a significant difference in the two treated series at $48 \mathrm{~h}\left(\mathrm{~F}_{2.8}=208.19 ; \mathrm{p}=0.000\right)$ and $96 \mathrm{~h}\left(\mathrm{~F}_{2.8}=7025.45 ; \mathrm{p}=0.000\right)$ as compared to 
control, with pronounced effect in $\mathrm{Cl}_{25}$ treated series. The three-way ANOVA showed significant effects of $\mathrm{Cd}$ concentration $\left(\mathrm{F}_{2.53}=2074.06 ; \mathrm{p}=0.000\right)$ and exposure time $\left(\mathrm{F}_{2.53}=2470.09 ; \mathrm{p}=0.000\right)$, and $\operatorname{sex}\left(\mathrm{F}_{1.53}=506.26 ; \mathrm{p}=0.000\right)($ Table A35 $)$.

Table 3. Effect of Cd on metallic elements ( $\mu \mathrm{g} / \mathrm{g}$ of dry weight) in D. trunculus females ( $m \pm S D . n=3)$. (Means for the same time exposure (the rows) followed by the different letter in miniscule are significantly different, while for each treatment (the columns), values followed by the different letter in majuscule are significantly different at $p \leq 0.05$ )

\begin{tabular}{|c|c|c|c|c|}
\hline \multirow{2}{*}{$\begin{array}{l}\text { Metallic elements } \\
\text { ( } \mu \mathrm{g} / \mathrm{g} \text { dry weight })\end{array}$} & \multirow{2}{*}{$\begin{array}{c}\text { Exposure time } \\
\text { (h) }\end{array}$} & \multicolumn{3}{|c|}{ Treatment } \\
\hline & & Control & $\mathrm{LC}_{10}$ & $\mathbf{L C}_{25}$ \\
\hline $\mathrm{Ca}$ & $\begin{array}{c}0 \\
48 \\
96\end{array}$ & $\begin{array}{l}624.54 \pm 4.75 \mathbf{a A} \\
621.61 \pm 1.64 \mathbf{a A} \\
621.21 \pm 1.20 \mathbf{a A}\end{array}$ & $\begin{array}{l}624.54 \pm 4.75 \mathbf{a A} \\
619.83 \pm 0.57 \mathbf{b B} \\
354.37 \pm 2.57 \mathbf{b C}\end{array}$ & $\begin{array}{l}624.54 \pm 4.75 \mathbf{a A} \\
310.66 \pm 1.00 \mathbf{c B} \\
305.04 \pm 3.26 \mathbf{c B}\end{array}$ \\
\hline $\mathrm{Fe}$ & $\begin{array}{c}0 \\
48 \\
96 \\
\end{array}$ & $\begin{array}{l}149.71 \pm 1.94 \mathbf{a A} \\
148.83 \pm 0.06 \mathbf{a A} \\
147.33 \pm 0.47 \mathbf{a A}\end{array}$ & $\begin{array}{c}149.71 \pm 1.94 \mathbf{a A} \\
130.50 \pm 4.69 \mathbf{b B} \\
95.58 \pm 2.70 \mathbf{b C}\end{array}$ & $\begin{array}{c}149.71 \pm 1.94 \mathbf{a A} \\
104.83 \pm 1.45 \mathbf{c B} \\
86.66 \pm 1.70 \mathbf{c C}\end{array}$ \\
\hline $\mathrm{Zn}$ & $\begin{array}{c}0 \\
48 \\
96\end{array}$ & $\begin{array}{l}91.12 \pm 0.45 \mathbf{a A} \\
90.33 \pm 0.06 \mathbf{a A} \\
89.70 \pm 0.90 \mathbf{a A}\end{array}$ & $\begin{array}{l}91.12 \pm 0.45 \mathbf{a A} \\
76.29 \pm 0.79 \mathbf{b B} \\
60.99 \pm 0.64 \mathbf{b C}\end{array}$ & $\begin{array}{l}91.12 \pm 0.45 \mathbf{a A} \\
70.83 \pm 0.56 \mathbf{c B} \\
54.04 \pm 0.85 \mathbf{c C}\end{array}$ \\
\hline $\mathrm{Cd}$ & $\begin{array}{c}0 \\
48 \\
96\end{array}$ & $\begin{array}{l}4.45 \pm 0.90 \mathbf{a A} \\
4.87 \pm 0.21 \mathbf{a A} \\
5.24 \pm 0.33 \mathbf{a A}\end{array}$ & $\begin{array}{c}4.45 \pm 0.90 \mathbf{a A} \\
14.79 \pm 0.06 \mathbf{b B} \\
15.25 \pm 0.43 \mathbf{b B}\end{array}$ & $\begin{array}{c}4.45 \pm 0.90 \mathbf{a A} \\
21.04 \pm 0.40 \mathbf{c B} \\
22.04 \pm 1.23 \mathbf{c B}\end{array}$ \\
\hline
\end{tabular}

Table 4. Effect of Cd on metallic elements ( $\mu \mathrm{g} / \mathrm{g}$ of dry weight) in $\mathrm{D}$. trunculus males ( $m \pm S D . n=3$ ). (Means for the same time exposure (the rows) followed by the different letter in miniscule are significantly different, while for each treatment (the columns), values followed by the different letter in majuscule are significantly different at $p \leq 0.05$ )

\begin{tabular}{c|c|c|c|c}
\hline $\begin{array}{c}\text { Metallic elements } \\
(\boldsymbol{\mu g} / \mathbf{g} \text { dry weight })\end{array}$ & $\begin{array}{c}\text { Exposure time } \\
(\mathbf{h})\end{array}$ & $\mathbf{C o n t r o l}$ & $\mathbf{L} \mathbf{C}_{\mathbf{1 0}}$ & $\mathbf{L C}_{\mathbf{2 5}}$ \\
\cline { 3 - 5 } & 0 & $340.95 \pm 0.80 \mathbf{a A}$ & $340.95 \pm 0.80 \mathbf{a A}$ & $340.95 \pm 0.80 \mathbf{a A}$ \\
$\mathrm{Ca}$ & 48 & $339.95 \pm 0.87 \mathbf{a A}$ & $282.70 \pm 3.09 \mathbf{b B}$ & $270.29 \pm 2.19 \mathbf{c B}$ \\
& 96 & $339.66 \pm 0.28 \mathbf{a A}$ & $264.21 \pm 1.79 \mathbf{b C}$ & $212.91 \pm 1.80 \mathbf{c C}$ \\
\hline & 0 & $86.54 \pm 0.25 \mathbf{a A}$ & $86.54 \pm 0.25 \mathbf{a A}$ & $86.54 \pm 0.25 \mathbf{a A}$ \\
$\mathrm{Zn}$ & 48 & $84.33 \pm 2.74 \mathbf{a A}$ & $74.25 \pm 1.11 \mathbf{b B}$ & $53.75 \pm 1.32 \mathbf{c B}$ \\
& 96 & $85.62 \pm 0.66 \mathbf{a A}$ & $63.03 \pm 0.38 \mathbf{b C}$ & $41.66 \pm 0.18 \mathbf{c C}$ \\
\hline & 0 & $73.71 \pm 4.19 \mathbf{a A}$ & $73.71 \pm 4.19 \mathbf{a A}$ & $73.71 \pm 4.19 \mathbf{a A}$ \\
$\mathrm{Fe}$ & 48 & $70.45 \pm 0.58 \mathbf{a A}$ & $68.50 \pm 0.56 \mathbf{a b A B}$ & $66.12 \pm 2.25 \mathbf{b B}$ \\
& 96 & $68.74 \pm 0.37 \mathbf{a A}$ & $63.33 \pm 1.82 \mathbf{b B}$ & $53.12 \pm 1.47 \mathbf{c C}$ \\
\hline & 0 & $4.20 \pm 0.40 \mathbf{a A}$ & $4.20 \pm 0.40 \mathbf{a A}$ & $4.20 \pm 0.40 \mathbf{a A}$ \\
$\mathrm{Cd}$ & 48 & $4.87 \pm 0.43 \mathbf{a A}$ & $5.20 \pm 0.40 \mathbf{a A}$ & $13.75 \pm 1.21 \mathbf{b B}$ \\
& 96 & $4.58 \pm 0.57 \mathbf{a A}$ & $7.53 \pm 0.94 \mathbf{b B}$ & $15.45 \pm 0.38 \mathbf{c B}$ \\
\hline
\end{tabular}

\section{Cadmium contents}

A significant increase of $\mathrm{Cd}$ contents was observed in two groups of treated series as compared to control series in both sexes. Also, the Cd contents differed significantly in the two treated series at $48 \mathrm{~h}\left(\mathrm{~F}_{2.8}=2811.72 ; \mathrm{p}=0.000\right)$ and $96 \mathrm{~h}\left(\mathrm{~F}_{2.8}=352.97\right.$; 
$\mathrm{p}=0.000)$ as compared to control in females, with marked effect in $\mathrm{Cl}_{25}$ treated series (Tables 3, A36 and A37). In D. trunculus males (Tables 4, A38 and A39), the Cd contents were significantly different significantly in the two treated series at $48 \mathrm{~h}\left(\mathrm{~F}_{2}\right.$. $\left.{ }_{8}=126.27 ; \mathrm{p}=0.000\right)$ and $96 \mathrm{~h}\left(\mathrm{~F}_{2.8}=206.78 ; \mathrm{p}=0.000\right)$ as compared to control, with more effect in $\mathrm{Cl}_{25}$ treated series at $96 \mathrm{~h}$. The three-way ANOVA indicated significant effects of concentration $\left(\mathrm{F}_{2 .}{ }_{53}=770.06 ; \mathrm{p}=0.000\right)$ and exposure time $\left(\mathrm{F}_{2 .}{ }_{53}=636.93\right.$; $\mathrm{p}=0.000)$ and $\operatorname{sex}\left(\mathrm{F}_{1.53}=390.76 ; \mathrm{p}=0.001\right)($ Table A40).

Regarding all ME, our results showed that the order of ME in D. trunculus females is as follows: $\mathrm{Ca}>\mathrm{Fe}>\mathrm{Zn}>\mathrm{Cd}$. $\mathrm{Ca}$ and $\mathrm{Fe}$ are the most abundant elements, and $\mathrm{Cd}$ is a scarce element. In D. trunculus males, the gradient of ME becomes as follows: $\mathrm{Ca}>\mathrm{Zn}$ $>\mathrm{Fe}>\mathrm{Cd}$. It is worth noting that $\mathrm{Ca}$ and $\mathrm{Zn}$ are the main abundant elements in males.

\section{Correlation tests}

\section{Pearson correlation tests between cadmium and proximate composition}

Pearson correlation tests between the proximate composition and the contents of $\mathrm{Cd}$ in both sexes of $D$. trunculus are displayed in Table 5. Here, the results revealed a highly significant $(\mathrm{p}=0.000)$ negative correlation between $\mathrm{Cd}$ and dry matter; and $\mathrm{Cd}$ and Fat content in both sexes. Conversely, a highly significant (0.000) positive correlation was noticed between $\mathrm{Cd}$ content and moisture content, and $\mathrm{Cd}$ content and ash content in both sexes.

\section{Pearson correlation tests between cadmium and metallic elements}

The relationships between ME in both sexes of $D$. trunculus are illustrated in Table 5. The Pearson correlation displayed a highly significant $(\mathrm{p}=0.000)$ negative correlation between $\mathrm{Cd}$ and other ME in both sexes.

Table 5. Pearson correlation tests between all parameters studies in D. trunculus females and males $(R=$ coefficient of correlation. $p=$ significance at $P<0.05)$

\begin{tabular}{c|c|c|c|c}
\hline \multirow{2}{*}{ Pearson correlation } & \multicolumn{2}{|c|}{ Females } & \multicolumn{2}{c}{ Males } \\
\cline { 2 - 5 } & $\mathbf{R}$ & $\mathbf{P}$ & $\mathbf{R}$ & $\mathbf{P}$ \\
\hline Dry matter $-\mathrm{Cd}$ & -0.875 & 0.000 & -0.779 & 0.000 \\
Fat- Cd & -0.838 & 0.000 & -0.826 & 0.000 \\
Moisture $-\mathrm{Cd}$ & 0.917 & 0.000 & 0.779 & 0.000 \\
$\mathrm{Ash}-\mathrm{Cd}$ & 0.924 & 0.000 & 0.875 & 0.000 \\
$\mathrm{Zn}-\mathrm{Cd}$ & -0.921 & 0.000 & -0.950 & 0.000 \\
$\mathrm{Fe}-\mathrm{Cd}$ & -0.930 & 0.000 & -0.799 & 0.000 \\
$\mathrm{Ca}-\mathrm{Cd}$ & -0.981 & 0.000 & -0.861 & 0.000 \\
\hline
\end{tabular}

\section{Discussion}

The consumers' awareness about proximate composition and ME contents of any edible organism which are commonly threatened by the usage of the coastal waters (simple wastes repository) is exceedingly important (Akpor et al., 2014; Ehsanuddin et al., 2019). Our study provides a helpful understanding of the changes in the nutritive value of $D$. trunculus exposed to cadmium contaminated Gulf of Annaba. Very limited 
studies investigating the impact of heavy metals (no essential metallic elements) on the proximate and essential ME of bivalvia (Bejaoui et al., 2020) are available.

\section{Impact of sub-lethal concentrations of cadmium on moisture contents}

In this study, we found that the mean percentage of moisture contents in D. trunculus controls was $77.40 \%$ and $75.40 \%$ for females and males respectively. Similar results were previously reported for the same and other species of bivalvia (Appukuttan and Aravindan, 1995; Mc Lean and Bulling, 2005; Hussein, 2015; Ogidi et al., 2020). In fact, the significant change in the percentage of moisture contents could reflect an index of the freshness of edible mollusks (Ghribi et al., 2018; Bejaoui et al., 2020). Besides, our results revealed an increase in the percentage of moisture contents with the two test concentrations in both sexes during the exposure periods. This is likely due to tissue alterations following an intense uptake of body water after an energetic metabolic degradation (Vargasmachuca et al., 2017; Hussain et al., 2018). Our results are in agreement with a previous study (Krishnakumari and Nair, 1984) conducted in oyster Saccostrea cucullata from different sites (polluted site and a relatively clean site). Of note, the moisture content was influenced by the surrounding environment (Hussein, 2015).

\section{Impact of sub-lethal concentrations of cadmium on dry matter contents}

D. trunculus controls showed values of the mean percentage of dry matter contents between $22.49 \%$ and $24.59 \%$ for females and males, respectively. This result is alike to that found in Mercenaria mercenaria from Nigeria (Ogidi et al., 2020). Findings showed also a marked decrease in the percentage of dry matter contents in both sexes treated with the two concentrations during the exposure period. This result could be due to the increased moisture contents, indicating thus that the dry matter is the remaining material after the removal process of water.

\section{Impact of sub-lethal concentrations of cadmium on ash contents}

The mean percentage of ash content in D. trunculus controls is $2.06 \%$ and $1.20 \%$ for females and males respectively. This was similar to that reported in other bivalve species such as Laternula elliptica (Ahn et al., 2003); Anodonta woodiana (Hartono, 2007); Meretrix meretrix and Pholas dactylus (Ghifari, 2011); Batissa violacea (Jamaluddin et al., 2016). A significant increase in the percentage of ash contents was detected in both sexes exposed to the two tested concentrations as compared to the controls. This result might be related to the increase of the $\mathrm{Cd}$ in soft tissues. Similarly, a previous study conducted on Anodonta anatine exposed to various doses of $\mathrm{Pb}, \mathrm{Cu}$, and $\mathrm{Cr}$ in water has reported a marked increase in the ash content (Sohail et al., 2016). Furthermore, the moisture content exhibited a positive correlation with ash content, because the acquisition of moisture leads to an acquisition of inorganic water-soluble compounds (Bochi et al., 2008).

\section{Impact of sub-lethal concentrations of cadmium on fat contents}

The obtained results revealed that the mean percentage of fat contents in D. trunculus controls is between $1.78 \%$ and $1.27 \%$ for females and males respectively. Previous studies, including those conducted on Anodonta woodiana (Hartono, 2007); Meretrix 
meretrix and Pholas dactylus (Ghifari, 2011) concord with our finding. The low-fat content represents a nutritional characteristic of the mollusk flesh (Bellisle et al., 1999; Wen et al., 2020). Further, the percentage of fat contents was significantly decreased in $D$. trunculus subjected to the two tested concentrations as compared to the control group of both sexes. This result might be owed to the increase of the Cd content in soft tissues, exhibiting a negative correlation with fat contents. In this context, a comparable tendency was estimated by Bejaoui et al. (2020) for lipids and reserve lipids in Venerupis decussata tissue from two Tunisian lagoons exposed to different anthropogenic contaminants.

\section{Impact of sub-lethal concentrations of cadmium on essential metallic elements contents}

Regarding the contents of EM, our study indicated that the predominant EM detected in both sexes of D. trunculus controls is Ca. This finding concords with other previous studies conducted on Donax cuneatus (Idayachandiran et al., 2014), Perna viridis and Villoritta cyprinoids (Ragi et al., 2017), Anomalocardia brasiliensis and Mytella guyanensis (Costa et al., 2019). Moreover, a negative correlation between $\mathrm{Cd}$ and $\mathrm{Ca}$ has been noticed in both sexes, and the Cd exposure at two sub-lethal concentrations was found to likely reduce the levels of $\mathrm{Ca}$. Also, $\mathrm{Cd}$ was reported to affect $\mathrm{Ca}$ metabolism in bivalve mollusks (Faubel et al., 2008), through a competitive interaction in the plasma membrane binding site of $\mathrm{Ca}$. Additionally, $\mathrm{Cd}$ affects the $\mathrm{SH}$ groups of Ca-ATPase (Verbost et al., 1988), resulting consequently in decreased Ca levels in soft tissue. This finding is similar to previous studies performed on Donax rugosus (Sidoumou et al., 1997), Crassostrea gaster (Javanshir and Shapoori, 2011) and Anodonta anatina (Ngo et al., 2011).

In this study, Fe was proved as the second most abundant element in D. trunculus female controls, and this was similarly reported in previous studies performed on samesex of the same species or other species (Romeo and Gnassia-Barelli, 1988; El-Serehy et al., 2013; Richir and Gobert, 2014). Furthermore, a negative correlation between Cd and Fe was observed in both sexes, and accordingly, the decreased level of Fe at two sub-lethal concentrations was also detected in Mizuhopecten yessoensis (Chelomin et al., 1995). Fe plays an essential role in antioxidant enzyme activities like catalase whose activity can be affected by $\mathrm{Fe}$ variations. In this regard, Soltani et al. (2012) have reported disruption in catalase activity in a mantle of $D$. trunculus collected from $\mathrm{Cd}$ polluted northeast Algeria sites (Sidi Salem beach, Annaba city). Besides, D. trunculus controls males were found to contain abundantly zinc element whose cellular uptake is higher in sperm than eggs in M. edulis (Latouche and Mix, 1981; Akberali et al., 1985 in Earnshaw et al., 1986). Whilst, D. trunculus females are rich in $\mathrm{Zn}$ after $\mathrm{Fe}$ as compared to males. Similar results have been found in D. trunculus females from Italy (Marina and Enzo, 1983) and Mytilus galloprovincialis females from Belgium (Richir and Gobert, 2014). Findings showed also a negative correlation between $\mathrm{Cd}$ and $\mathrm{Zn}$, in addition to a decrease in $\mathrm{Zn}$ contents in soft tissues of $D$. trunculus in both sexes at two sub-lethal concentrations. This result was similar to that of a previous study conducted on Lamellidans marginalis (Das and Jana, 1999) and Anodonta anatine (Ngo et al., 2011). The plausible explanation of this result is that $\mathrm{Cd}$ can affect the active sites of DNA-binding proteins, MTs, and Zn-containing enzymes (Pruskiand Dixon, 2002; Golovanova, 2008; Ngo et al., 2011). As reported, Zn protects against the toxicity of Cd (Kaji et al., 1988) whose each atom coordinates with seven zinc atoms (Giles, 1988). 
As $\mathrm{Cd}$ is a non-essential element, both sexes showed the lowest contents of these elements in the control series. Importantly, these values are less than the permissible limit recommended by CEFAS (1997) and NHMRC (1987). Also, the incorporation of $\mathrm{Cd}$ increased as a function of the concentration and the exposure time in both sexes. Our results are in line with the study of Belabed and Solatni (2018) reporting that $D$. trunculus is sensitive to Cd toxicity. This metal was gradually incorporated into the body. D. trunculus responds quickly with a relatively effective detoxification process, since a reduction in the levels of $\mathrm{Cd}$ in tissue was observed starting at $96 \mathrm{~h}$ during the recovery period. Moreover, the effect of $\mathrm{LC}_{25}$ was relatively more significant, and accordingly, the Cd toxicity on PC, omega-3 fatty acids, EPA, DHA, carbohydrates, proteins, lipids for the same species and same concentrations have been previously reported (Merad et al., 2016, 2017; Merad and Soltani, 2017).

According to the literature, the values of EM contents in Donax were varied in different areas. This variation is strongly dependent on geochemical and biological factors (Gupta and Singh, 2011; Katsallah et al., 2013), including sexes, size, age, phenotype, genotype, feeding activity, and reproductive stage (Boening, 1997). The geochemical factors include organic carbon, water hardness, salinity, temperature, $\mathrm{pH}$, dissolved oxygen, sediment grain size, and hydrologic features of the system (Elder et al., 1991; Caçador et al., 2016).

Alike to previous studies (Laxmilatha, 2009; Richir and Gobert, 2014; Hussein, 2015) investigating the differences between the sexes in the proximate and EM contents, our data indicated higher contents on moisture, ash, fat, and EM in females than males of $D$. trunculus. This is likely due to the reason that the formation of reserves during the respawning period is more pronounced in females, suggesting that the accumulation of proximate and EM in this sex could be faster (Sokolowski et al., 2004). Accordingly, Merad et al. (2015) have reported a higher rate of MTs in $D$. trunculus females than males.

\section{Conclusion}

The present study provides valuable knowledge on the proximate and EM contents in D. trunculus from the gulf of Annaba (Northeast Algeria), as well as the impact of Cd on these parameters. D. trunculus was found to be rich in moisture contents and contains low ash and fat contents. $\mathrm{Ca}, \mathrm{Zn}$ and $\mathrm{Fe}$ were the main compounds in the flesh of $D$. trunculus. The contents of $\mathrm{Cd}$ in tissues can vary as a function of its concentration, exposure time, and sexes, which hence significantly affected the proximate and EM contents in $D$. trunculus. Thus, it is necessary to continue monitoring programs to control the metal concentrations and, subsequently to avoid health-associated problems.

Acknowledgements. This work was supported by the National Fund for Scientific Research to Pr. N. Soltani (Laboratory of Applied Animal Biology) and the Ministry of High Education and Scientific Research of Algeria (CNEPRU Project to Dr. A. Hamdani).

\section{REFERENCES}

[1] Ahn, I. Y., Surh, J., Park, Y. G., Kwon, H., Choi, K. S., Kang, S. H., Chung, H. (2003): Growth and seasonal energetics of the Antarctic bivalve Laternula elliptica from King 
George Island, Antarctica. - Marine Ecology Progress Series 257: 99-110. https://doi.org/10.3354/meps257099.

[2] Akberali, H. B., Earnshaw, M. J., Marriott, R. M. (1985): The action of heavy metals on the gametes of the marine mussel, Mytilus edulis (L.)-II. Uptake of copper and zinc and their effect on respiration in the sperm and unfertilized egg. - Marine Environmental Research 16(1): 37-59. https://doi.org/10.1016/0141-1136(85)90019-4.

[3] Akpor, O. B., Ohiobor, G. O., Olaolu, T. D. (2014): Heavy metal pollutants in waste water effluents: Sources, effects, and remediation. - Advances in Bioscience and Bioengineering 2(4): 37-43. https://doi.org/10.11648/J.ABB.20140204.11.

[4] Amira, A., Merad, I., Marisa, R., Almeida, G. L., Soltani, N. (2018): Seasonal variation in biomarker responses of Donax trunculus from the Gulf of Annaba (Algeria): implication of metal accumulation in sediments. - Comptes Rendus Geoscience 350(4): 173-179. https://doi.org/10.1016/j.crte.2018.02.002.

[5] AOAC Official Method 920.153-Ash of Meat (2000): Official Method of Analytical Chemists. 17th Ed. - Association of Official Analytical Chemists, Maryland.

[6] AOAC Official Method 960.39-Fat (Crude) or Ether Extract in Meat (2000): Official Method of Analytical Chemists. 17th Ed. - Association of Official Analytical Chemists, Maryland.

[7] Appukuttan, K. K., Aravindan, C. M. (1995): Studies on the biochemical composition of the short neck clam, Paphia malabarica from Ashtamudi estuary, Southwest coast of India. - Seafood Export Journal 26(5): 17-21.

[8] Astudillo, L. R., Yen, I. C., Bekele, I. (2005): Heavy metals in sediments, mussels and oysters from Trinidad and Venezuela. - Revista de Biología Tropical 53(1): S41-53.

[9] Bankaji, I., Pérez-Clemente, R. M., Caçador, I., Sleimi, N. (2019): Accumulation potential of Atriplex halimus to zinc and lead combined with $\mathrm{NaCl}$ : effects on physiological parameters and antioxidant enzymes activities. - South African Journal of Botany 123: 51-61. https://doi.org/10.1016/j.sajb.2019.02.011.

[10] Bejaoui, S., Bouaziz, M., Ghribi, F., Chetoui, I., El Cafsi, M. (2020): Assessment of the biochemical and nutritional values of Venerupis decussata from Tunisian lagoons submitted to different anthropogenic ranks. - Environmental Science and Pollution Research 27: 1734-1751. https://doi.org/10.1007/s11356-019-06851-y.

[11] Belabed, S., Soltani, N. (2013): Acute toxicity of cadmium on Donax trunculus: acetylcholinesterase, glutathione S-transferase activities and pattern of recovery. European Journal of Experimental Biology 3(2): 54-61.

[12] Belabed, S., Soltani, N. (2018): Effects of cadmium concentrations on bioaccumulation and depuration in the marine bivalve Donax trunculus. - Euro-Mediterranean Journal for Environmental Integration 3: 19. https://doi.org/10.1007/s41207-018-0054-0.

[13] Beldi, H., Gimbert, F., Maas, S., Scheifler, R., Soltani, N. (2006): Seasonal variations of $\mathrm{Cd}, \mathrm{Cu}, \mathrm{Pb}$ and $\mathrm{Zn}$ in the edible mollusc Donax trunculus (Mollusca Bivalvia) from the gulf of Annaba, Algeria. - African Journal Agricultural of Research 1(4): 85-90. https://doi.org/10.5897/AJAR-0AE486A36567.

[14] Bellisle, F. (1999): Glutamate and the umami taste: sensory, metabolic, nutritional and behavioural considerations. A review of the literature published in the last 10 years. Neuroscience Biobehavioral Reviews 23(3): 423-438. https://doi.org/10.1016/S01497634(98)00043-8.

[15] Bhobe, A. M., Pai, J. S. (1986): Study of the properties of frozen shrimps. - Journal of Food Science and Technology 23: 143-147.

[16] Bochi, V. C., Weber, J., Ribeiro, C. P., Victório, A. M., Emanuelli, T. (2008): Fishburgers with silver cat fish (Rhamdia quelen) filleting residue. - Bioresources Technology 99: 8844-8849. https://doi.org/10.1016/j.biortech.2008.04.075.

[17] Boening, D. W. (1997): An evaluation of bivalves as biomonitors of heavy metals pollution in marine waters. - Environmental Monitoring and Assessment 55: 459-470. http://dx.doi.org/10.1023/A: 1005995217901. 
[18] Bryan, G. W., Potts, G. W., Forester, G. R. (1977): Heavy metals in the gastropod mollusc Haliotis tuberculata (L.). - Journal of the Marine Biological Association UK (JMBA) 57: 379-390.

[19] Caçador, I., Duarte, B., Marques, J. C., Sleimi, N. (2016): Carbon Mitigation: A Salt Marsh Ecosystem Service in Times of Change. - In: Khan, M. A., Ozturk, M., Gul, B., Ahmed, M. Z. (eds.) Halophytes for Food Security in Dry Lands. Elsevier Academic Press, Cambridge, MA, pp. 83-110. https://doi.org/10.1016/B978-0-12-801854-5.000066.

[20] CEFAS, Centre for Environment, Fisheries and Aquaculture Science (1997): Monitoring and surveillance of non-radioactive contaminants in the aquatic environment and activities regulating the disposal of waste at sea (1994). - Aquatic Environment Monitoring Report 47. Centre for Environment, Fisheries, and Agriculture Science, Lowestoft, UK.

[21] Chelomin, V. P., Bobkova, E. A., Lukyanova, O. N., Chekmasova, N. M. (1995): Cadmium-induced alterations in essential trace element homoeostasis in the tissues of scallop Mizuhopecten yessoensis. - Comparative Biochemistry \& Physiology Part C 110: 329-335.

[22] Costa, V. C., Carqueija, A. F. A., Babos, D. V., Pereira-Filho, E. R. (2019): Direct determination of $\mathrm{Ca}, \mathrm{K}, \mathrm{Mg}, \mathrm{Na}, \mathrm{P}, \mathrm{S}, \mathrm{Fe}$ and $\mathrm{Zn}$ in bivalve mollusks by wavelength dispersive X-ray fluorescence (WDXRF) and laser-induced breakdown spectroscopy (LIBS). - Food Chemistry 273: 91-98. https://doi.org/10.1016/j.foodchem.2018.02.016.

[23] Costa, L. L., Costa, M. F., Zalmon, I. R. (2021): Macroinvertebrates as biomonitors of pollutants on natural sandy beaches: overview and meta-analysis. - Review Environmental Pollution 275: 116629. https://doi.org/10.1016/j.envpol.2021.116629.

[24] Das, S., Jana, B. B. (1999): Dose-dependent uptake and Eichhornia-induced elimination of cadmium in various organs of the freshwater mussel, Lamellidens marginalis (Linn.). Ecological Engineering 12(3-4): 207-29. https://doi.org/10.1016/S0925-8574(98)000627.

[25] Dhinamala, K., Pushpalatha, M., Meeran, M., Arivoli, S., Tennyson, S., Raveen, R. (2017): Bioaccumulation of cadmium in gills and muscles of shellfish from Pulicat lake, Tamil Nadu, India. - Journal of Coastal Life Medicine 5(2): 47-50. https://doi.org/10.12980/jclm.5.2017J6-210.

[26] Drif, F., Abdennour, C. (2010): Trace metals in the mussel Donax trunculus Linnaeus 1758 from urban and industrial contaminated locations. - Journal of Applied Sciences Research 6(12): 2063-2067.

[27] Dutta, M., Rajak, P., Khatun, S. (2017): Toxicity assessment of sodium fluoride in Drosophila melanogaster after chronic sub-lethal exposure. - Chemosphere 166: 255266. https://doi.org/10.1016/j.chemosphere.2016.09.112.

[28] Earnshaw, M. J., Wilson, S., Akberali, H. B. (1986): The action of heavy metals on the gametes of the marine mussel, Mytilus edulis (L.) - III. The effect of applied copper and zinc on sperm motility in relation to ultrastructural damage and intracellular metal localisation. - Marine of Environmental Research 20(4): 261-278.

[29] Ehsanuddin, N. A., Shafie, F. A., Abdullah, A. H., Mahalingam, S. R., Tiong, C. S., Arshad, K. (2019): Heavy metals in dried squids (Loligo sp.) in Melaka Tengah District. - MAEH Journal of Environmental Health 1(1): 24-27.

[30] Elder, J. F., Collins, J. J. (1991): Freshwater molluscs as indicators of bioavailability and toxicity of metals in surface water systems. - Reviews of Environmental Contamination and Toxicology 122: 37-79. https://doi.org/10.1007/978-1-4612-3198-1_2.

[31] El-Serehy, H. A., Aboulela, H., Al-Misned, F., Bahgat, M., Shafik, H., Al-Rasheid, K., Kaiser, M., Ezz, H. (2013): The potential use of the bivalve Donax trunculus as bioindicator for heavy metal pollution of port said western coast on the Mediterranean Sea. - Life Science Journal 10(4): 1094-1101. 
[32] Faubel, D., Lopes-Lima, M., Freitas, S., Pereira, L., Andrade, J., Checa, A., Frank, H., Matsuda, T., Machado, J. (2008): Effects of $\mathrm{Cd} 2+$ on the calcium metabolism and shell mineralization of bivalve Anodonta cygnea. - Marine Freshwater Behaviour and Physiology 41(2): 93-108. https://doi.org/10.1080/10236240802194123.

[33] Gaspar, M. B., Ferreira, R., Monteiro, C. (1999): Growth and reproductive cycle of Donax trunculus L. (Mollusca: Bivalvia) in Faro, southern Portugal. - Fish Research 41(3): 309-316. https://doi.org/10.1016/S0165-7836(99)00017-X.

[34] Gaspar, M. B., Chícharo, L. M., Vasconcelos, P., Garcia, A., Santos, A. R., Monteiro, C. C. (2002): Depth segregation phenomenon in Donax trunculus (Bivalvia: Donacidae) populations of the Algarve coast (southern Portugal). - Science Marine 66(2): 111-121. https://doi.org/10.3989/scimar.2002.66n2111.

[35] Ghifari, A. (2011): Karakteristik Asam Lemak Daging Keong Macan (Babylonia spirata), Kerang Tahu (Meretrix meretrix), Dan Kerang Salju (Pholas dactylus). [skripsi], Departemen Teknologi Hasil Perairan Fakultas Perikanan Dan Ilmu Kelautan Institut Pertanian Bogor, Bogor.

[36] Ghribi, F., Boussoufa, D., Aouini, F., Bejaoui, S., Chetoui, I., Rabeh, I., EL Cafsi, M. (2018): Seasonal variation of biochemical composition of Noah's ark shells (Arcanoae L. 1758) in Tunisian coastal lagoon in relation to its reproductive cycle and environmental conditions. - Aquatic Living Resources 31: 14. https://doi.org/10.1051/alr/2018002.

[37] Gil, A., Gil, F. (2015): Fish, a Mediterranean source of n-3 PUFA: benefits do not justify limiting consumption. - British Journal of Nutrition 113: 58-67. https://doi: 10.1017/S0007114514003742.

[38] Giles, M. A. (1988): Accumulation of cadmium by rainbow trout, Salmo gairdneri, during extended exposure. - Canadian Journal of Fisheries Aquatic Sciences 45: 10451053.

[39] Golovanova, I. L. (2008): Effects of heavy metals on the physiological and biochemical status of fishes and aquatic invertebrates. - Inland Water Biology 1: 93-101. https://doi.org/10.1007/s12212-008-1014-1.

[40] Gupta, S. K., Singh, J. (2011): Evaluation of mollusc as sensitive indicator of heavy metal pollution in aquatic system. A review. - Institute of Integrative Omics and Applied Biotechnology Journal 2(1): 49-57.

[41] Hafsaoui, I., Draredja, B., Lasota, R., Como, S., Magni, P. (2016): Population dynamics and secondary production of Donax trunculus (Mollusca, Bivalvia) in the Gulf of Annaba (Northeast Algeria). - Mediterranean Marine Science 17(3): 738-750. https://doi.org/10.12681/mms.1760.

[42] Hamdani, A., Soltani, N., Zaidi, N. (2020): Growth and reproduction of Donax trunculus from the Gulf of Annaba (Northeast Algeria) in relation to environmental conditions. Environmental Science and Pollution Research 27: 41656-41667. https://doi.org/10.1007/s11356-020-10103-9.

[43] Hartono, N. (2007): Pengaruh Berbagai Metode Pemaaakan Terhadap Kelarutan Mineral Kijing Taiwan (Anodonta woodiana Lea) [Skripsi]. - Departemen Teknologi Hasil Perairan, Fakultas Perikanan dan Ilmu Kelautan, IPB. http://repository.ipb.ac.id/handle/123456789/48718.

[44] Hossen, M. F., Hamdan, S., Rahman, M. R. (2015): Review on the risk assessment of heavy metals in Malaysian clams. - Science World Journal 1-7. https://doi.org /10. 1155 /2015/905497.

[45] Hussain, B., Sultana, T., Sultana, S., Ahmed, Z., Mahboob, S. (2018): Study on impact of habitat degradation on proximate composition and amino acid profile of Indian major carps from different habitats. - Saudi Journal of Biological Sciences 25(4): 755-759. https://doi.org/10.1016/j.sjbs.2018.02.004. 
[46] Hussein, S. M. (2015): Water content as a new tool for discrimination between some shellfishes. - Pakistan Journal of Biological Sciences 18: 204-214. https://doi.org/10.3923/pjbs.2015.204.214.

[47] Idayachandiran, G., Muthukumar, A., Kumaresan, S., Balasubramanian, T. (2014): Nutritional value of marine bivalve, Donax cuneatus (Linnaeus, 1758) from Cuddalore coastal waters, southeast coast of India. - Inventi Impact: Life Style 1: 15-19.

[48] Jamaluddin, M., Septiawan, Y., Yonelian, Y. (2016): Analysis of fatty acid and amino acid profile of "Meti" mussels (Batissa violacea L. von Lamarck, 1818) in La'a river of Petasia District North Morowali regency. - Rasayan Jounal of Chemistry 9(4): 673-679.

[49] Javanshir, A., Shapoori, M. (2011): Influence of water hardness (calcium concentration) on the absorption of cadmium by the mangrove oyster Crassostrea gaster (Ostreidae; Bivalvia). - Journal of Food, Agriculture and Environment 9(2): 724-727.

[50] Kaji, T., Takata, M., Hoshino, T., Miyahara, T., Kozuka, H., Kurashige, Y., Koizumi, F. (1988): Role of zinc in protection against cadmium induced toxicity in formation of embryonic chick bone in tissue culture. - Toxicology Letters 44: 219-27. https://doi.org/10.1016/0378-4274(88)90149-X.

[51] Katsallah, G. I. M., Rukayya, M., Sambo, D., Sule, T. G. (2013): Comparative metal analysis of the soft tissues of three species of Anodonta (Class: Bivalvia) from Kubanni Lake in Zaria Nigeria. - Journal of Environmental Science, Toxicology and Food Technology 6(3): 18-23. https://doi.org/10.9790/2402-0631823.

[52] Khan, P. A. (1992): Biochemical composition, minerals (calcium and iron) and chitin content of two portunid crabs Scylla serrata Forskal and Portunus pelagicus Linnaeus available in and around the coastal regions of Bangladesh. - M.Sc. Thesis, Institute of Marine Sciences, Chittagong University.

[53] Krishnakumari, L., Nair, V. R. (1984): On the water quality of selected environments along Bombay coast. - Journal of the Indian Fisheries Association 14-15: 49-57.

[54] Künili, I. E., Çolakoğlu, S., Çolakoğlu, F. (2020): Levels of PAHs, PCBs, and toxic metals in Ruditapes philippinarum and Donax trunculus in Marmara Sea, Turkey. Journal of the Science of Food and Agriculture 101(3): 1167-1173. https://doi.org/10.1002/jsfa.10728.

[55] La Valle, P. (2006): Donax trunculus (Bivalvia: Donacidae) quale indicatore biologico degli equilibri costieri e del bilancio sedimentario. - Doctoral Thesis. University of Rome La Sapienza.

[56] Larpent, J. P. (1997): Microbiologie alimentaire technique de laboratoire. - Technique et documentation. Lavoisier, Paris, pp. 882-883.

[57] Latouche, Y. D., Mix, M. C. (1981): Seasonal variation in soft tissue weights and trace metal burdens in the bay mussel, Mytilus edulis. - Bulletin of Environmental Contamination and Toxicology 27(1): 821-828.

[58] Laxmilatha, P. (2009): Proximate composition of the surf clam Mactra violacea (Gmelin 1791). - Indian Journal of Fisheries 56(2): 147-150.

[59] Margret, S. M. (2015): A Survey on biodiversity of molluscs in trash fish landing of Colachal and Kadipatinam and searching of gastropods and bivalves for human consumption. - Ph. D. Thesis, Manonmaniam Sundaranar University, India, pp. 25-31.

[60] Margret, S. M., Santhiya, M., Mary, M. T., Jansi, M. (2013): Comparative study on the biochemical composition of four gastropods along the Kanyakumari coast. - World Journal of Fish and Marine Sciences 5: 637-40.

[61] Marina, M., Enzo, O. (1983): Variability of zinc and manganese concentrations in relation to sex and season in the bivalve Donax trunculus. - Marine Pollution Bulletin 14: 342-346.

[62] Mc Lean, C. H., Bulling, K. R. (2005): Differences in lipid profile of New Zealand marine species over four seasons. - Journal of Food Lipids 12(4): 313-326. https://doi.org/10.1111/j.1745-4522.2005.00026.x. 
[63] Merad, I., Soltani, N. (2015): Environmental risks of cadmium on Donax trunculus (Mollusca, Bivalvia): sublethal effect on nucleic acid contents of gonads. - Proceeding of INOC International Congress "Estuaries \& Coastal Protected Areas" ECPA 2014, 04-06 November 2014, Izmir, Turkey, pp. 260-267.

[64] Merad, I., Soltani, N. (2017): Sublethal effects of cadmium on energy reserves in the edible mollusk Donax trunculus. - Journal Entomology Zoology Studies 5(1): 100-105.

[65] Merad, I., Rabei, A., Soltani, N. (2015): Réponse de la métallothionéine au cours de l'exposition au cadmium et la restauration chez Donax trunculus. Bulletin de l'Institut National des Sciences de la Mer (INSTM Salammbo). - Numéro Spécial (18): Actes du IXème Congrès Maghrébin des Sciences de la Mer Sousse, 2014.

[66] Merad, I., Bairi, Y., Sifi, K., Soltani, N. (2016): Protein carbonyls as biomarkers of oxidative stress induced by cadmium in Donax trunculus gonad contents during exposure and recovery. - Fresenius Environmental Bulletin 25: 5889-5895.

[67] Merad, I., Bellenger, S., Hichami, A., Khan, N. A., Soltani, N. (2017): Effect of cadmium exposure on essential omega-3 fatty acids in the edible bivalve Donax trunculus. Environmental Science and Pollution Research 25: 18242-18250. https://doi.org/10.1007/s11356-017-9031-4.

[68] Mouabad, A. (1991): Toxicité comportementale et physiologique (filtration, respiration) des métaux lourds (cu, zn, hg, cd et pb) chez la moule d'eau douce Dreissena polymorpha pallas. - Thése de Doctorat en Ecotoxicologie, Université de Metz.

[69] Ngo, S., Gu, L., Guo, Z. (2011): Hierarchical organization in the amyloid core of yeast prion protein Ure2. - Journal of Biological Chemistry 286(34): 29691-9.

[70] NHMRC (National Health and Medical Research Council) (1987): National Food Standard A 12: Metals and Contaminants in Food. - Australia Australian Government Publishing Service, Canberra.

[71] Obaiah, J., Vivek, Ch., Padmaja, B., Sridhar, D., Peera, K. (2020): Cadmium toxicity impact on aquatic organisms oxidative stress: implications for human health safety and environmental aspects. A review. - International Journal of Science and Research 9: 2277-8616.

[72] Ogidi, O. I., Charles, E. E., Onimisi, A. M., Amugeh, R. (2020): Assessment of Nutritional Properties and Heavy Metal Composition of African Giant Land Snails (Archachatina marginata) and Clams (Mercenaria mercenaria) from Ekowe Community. - European Journal of Nutrition Food and Safety. https://doi.org/ 10.9734/EJNFS/2020/v12i630242.

[73] Orban, E., Di Lena, G., Nevigato, T., Casini, I., Marzetti, A., Caproni, A. (2002): Seasonal changes in meat content, condition index and chemical composition of mussels (Mytilus galloprovincialis) cultured in two different Italian sites. - Food Chemistry 77(1): 57-65. https://doi.org/10.1016/S0308-8146(01)00322-3.

[74] Ounissi, M., Ziouch, O. R., Aounallah, O. (2014): Variability of the dissolved nutrient $(\mathrm{N}, \mathrm{P}, \mathrm{Si}$ ) concentrations in the bay of Annaba in relation to the inputs of the Seybouse and Mafragh estuaries. - Marine Pollution Bulletin 80(1-2): 234-244. https://doi.org/10.1016/j.marpolbul.2013.12.030.

[75] Patino, D. M., Otero, J., Louza'n, A., Ojea, J., Vazquez, S. N., Alvarez-Salgado, X. A. (2021): Wedge clam (Donax trunculus Linnaeus, 1758) reproduction: reproductive traits and environmental influence in the NW Iberian coast and contrast across Atlantic and Mediterranean waters. - Hydrobiologia 848: 1347-1366. https://doi.org/10.1007/s10750021-04532-x.

[76] Pruski, A. M., Dixon, D. R. (2002): Effects of cadmium on nuclear integrity and DNA repair efficiency in the gill cells of Mytilus edulis L. - Aquatic Toxicology 57(3): 127-37. https://doi.org/10.1016/s0166-445x(01)00192-8.

[77] Rabei, A., Hichami, A., Beldi, H., Bellenger, S., Akhtar Khan, N. A., Soltani, N. (2018): Fatty acid composition, enzyme activities and metallothioneins in Donax trunculus (Mollusca, Bivalvia) from polluted and reference sites in the Gulf of Annaba (Algeria): 
Pattern of recovery during transplantation. - Environmental Pollution 237: 900-907. https://doi.org/10.1016/j.envpol.2018.01.041.

[78] Ragi, A. S., Leena, P. P., Cheriyan, E., Nair, S. M. (2017): Heavy metal concentrations in some gastropods and bivalves collected from the fishing zone of South India. Marine Pollution Bulletin 118(1-2): 452-458. https://doi.org/10.1016/j.marpolbul.2017.03.029.

[79] Richir, J., Gobert, S. (2014): The effect of size, weight, body compartment, sex and reproductive status on the bioaccumulation of 19 trace elements in rope-grown Mytilus $\begin{array}{lllll}\text { galloprovincialis. } & - & \text { Ecology } & \text { Indicators } & 36:\end{array}$ https://doi.org/10.1016/j.ecolind.2013.06.021.

[80] Romeo, M., Gnassia-Barelli, M. (1988): Donax trunculus and Venus verrucosa as bioindicators of trace metal concentrations in Mauritanian costal waters. - Marine Biology 99: 223-227.

[81] Salama, A., Radwan, M. (2005): Heavy metals $(\mathrm{Cd}, \mathrm{Pb})$ and trace elements $(\mathrm{Cu}, \mathrm{Zn})$ contents in some foodstuffs from the Egyptian market. - Emirates Journal of Food and Agriculture 17(1): 34-42. https://doi.org/10.9755/ejfa.v12i1.5046.

[82] Sall, M. L., Diagne, D. A. K., Gningue-Sall, D., Aaron, S. E., Aaron, J. J. (2020): Toxic heavy metals: impact on the environment and human health, and treatment with conducting organic polymers, a review. - Environmental Science and Pollution Research 27: 29927-29942. https://doi.org/10.1007/s11356-020-09354-3.

[83] Sidoumou, Z., Gnassia-Barelli, M., Roméo, M. (1997): Cadmium and calcium uptake in the mollusc Donax rugosus and effect of a calcium channel blocker. - Bulletin of Environmental Contamination and Toxicology 58(2): 318-25. https://doi.org/10.1007/s001289900337.

[84] Sleimi, N., Kouki, R., HadjAmmar, M., Ferreira, R., Perez-Clemente, R. (2021): Barium effect on germination, plant growth, and antioxidant enzymes in Cucumis sativus L. plants. - Food Science \& Nutrition 9(4): 2086-2094. https://doi.org/10.1002/fsn3.2177.

[85] Sohail, M., Khan, M. N., Chaudhry, A. S., Qureshi, N. A. (2016): Bioaccumulation of heavy metals and analysis of mineral element alongside proximate composition in foot, gills and mantle of freshwater mussels (Anodonta anatina). - Rendiconti Lincei. Scienze Fisiche e Naturali 27: 687-696. https://doi.org/ 10.1007/s12210-016-0551-5.

[86] Sokolowski, A., Bawazir, A. S., Wolowicz, M. (2004): Trace metals in the brown mussel Perna perna from the coastal waters off Yemen (Gulf of Aden): how concentrations are affected by weight, sex, and seasonal cycle. - Archives of Environmental Contamination and Toxicology 46: 67-80. https://doi.org/ 10.1007/s00244-003-2164-0.

[87] Soltani, N., Amira, A., Sifi, K., Beldi, H. (2012): Environmental monitoring of the Annaba gulf (Algeria): measurement of biomarkers in Donax trunculus and metallic pollution. - Bullettin de la Société Zoologique de France 137(1-4): 47-56.

[88] Tlili, S., Mouneyrac, C. (2019): The wedge clam Donax trunculus as sentinel organism for Mediterranean coastal monitoring in a global change context. - Regional Environmental Change 19: 995-1007. https://doi.org/10.1007/s10113-018-1449-9.

[89] Tulonen, T., Pihlström, M., Lauri, A., Martti, R., 2006. Concentration of heavy metals in food wed components of small, boreal lakes. - Boreal Environmental Research 11: 185194.

[90] Vargasmachuca, S. G. C., Ponce-Palafox, J., Arambul-Munoz, E., Lopez- Gomez, C., Arredondo-Figueroa, J. L., Spanopoulos-Herandez, M. (2017): The combined effects of salinity and temperature on the proximate composition and energetic value of spotted rose snapper Lutjanus guttatus (Steindachnar, 1869). - Latin American Journal Aquatic Research 45: 1054-1058. http://dx.doi.org/10.3856/vol45-issue5-fulltext-20.

[91] Verbost, P. M., Flik, G., Lock, R. A. C., Bonga, S. E. W. (1988): Cadmium inhibits plasma membrane calcium transport. - The Journal of Membrane Biology 102: 97-104.

[92] Vieira, K. S., Crapez, M. A. C., Lima, L. S., Delgado, J. F., Brito, E. B. C. C., Fonseca E. M., Baptista, N. J. A., Aguia, V. M. C. (2021): Evaluation of bioavailability of trace 
metals through bioindicators in an urbanized estuarine system in southeast Brazil. Environmental Monitoring and Assessment 193-18. https://doi.org/10.1007/s10661-02008809-X.

[93] Wen, X., Chen, A., Wu, Y., Yang, Y., Xu, Y., Xia, W., Zhang, Y., Cao, Y., Chen, S. (2020): Comparative evaluation of proximate compositions and taste attributes of three Asian hard clams (Meretrix meretrix) with different shell colors. - International Journal of Food Properties 23(1): 400-411. https://doi.org/10.1080/10942912.2020.1733015.

[94] Wright, A. C., Fan, Y., Baker, G. L. (2018): Nutritional value and food safety of bivalve mollusc and shellfish. - Journal of Shellfish Research (37) 4: 695-708. https://doi.org/10.2983/035.037.0403.

[95] Yusoff, N. A. M., Long, S. M. (2011): Comparative bioaccumulation of heavy metals $(\mathrm{Fe}, \mathrm{Zn}, \mathrm{Cu}, \mathrm{Cd}, \mathrm{Cr}, \mathrm{Pb})$ in different edible mollusc collected from the estuary area of Sarawak River. - Proceedings of the University Malaysia Terengganu, 10th International Annual Symposium (UMTAS'11) 4-10. https://doi.org/10.1155/2014/924360.

[96] Zhang, Y., Jacob, D. J., Horowitz, H. M., Chen, L., Amos, H. M., Krabbenhoft, D. P., Sunderland, E. M. (2016): Observed decrease in atmospheric mercury explained by global decline in anthropogenic emissions. - Proceedings of the National Academy of Sciences 113(3): 526-531. https://doi.org/10.1 073/pnas.1516312113.

\section{APPENDIX}

Table A1. One-way analysis of variance (ANOVA) of moisture contents for females at $48 \mathrm{~h}$

\begin{tabular}{c|c|c|c|c|c}
\hline Source & df & SS & MS & F & P value \\
\hline Concentration & 2 & 21.05 & 10.527 & 9.34 & 0.006 \\
Error & 9 & 10.15 & 1.127 & & \\
Total & 11 & 31.20 & & & \\
\hline
\end{tabular}

Table A2. One-way analysis of variance (ANOVA) of moisture contents for females at $96 \mathrm{~h}$

\begin{tabular}{c|c|c|c|c|c}
\hline Source & df & SS & MS & F & P value \\
\hline Concentration & 2 & 59.655 & 29.8275 & 48.17 & 0.000 \\
Error & 9 & 5.573 & 0.6192 & & \\
Total & 11 & 65.228 & & & \\
\hline
\end{tabular}

Table A3. One-way analysis of variance (ANOVA) of moisture contents for males at $48 \mathrm{~h}$

\begin{tabular}{c|c|c|c|c|c}
\hline Source & df & SS & MS & F & P value \\
\hline Concentration & 2 & 21.15 & 10.576 & 6.45 & 0.018 \\
Error & 9 & 14.75 & 1.639 & & \\
Total & 11 & 35.90 & & & \\
\hline
\end{tabular}

Table A4. One-way analysis of variance (ANOVA) of moisture contents for males at $96 \mathrm{~h}$

\begin{tabular}{c|c|c|c|c|c}
\hline Source & df & SS & MS & F & P value \\
\hline Concentration & 2 & 65.44 & 32.722 & 26.58 & 0.000 \\
Error & 9 & 11.08 & 1.231 & & \\
Total & 11 & 76.52 & & & \\
\hline
\end{tabular}


Table A5. Three-way analysis of variance (ANOVA) of moisture contents

\begin{tabular}{c|c|c|c|c|c}
\hline Source & df & SS & MS & F & P value \\
\hline Concentration & 2 & 101.247 & 50.6233 & 49.05 & 0.000 \\
Time & 2 & 132.016 & 66.0081 & 63.96 & 0.000 \\
Sex & 1 & 75.502 & 75.5016 & 73.16 & 0.000 \\
Error & 54 & 55.729 & 1.0320 & & \\
Total & 71 & 430.641 & & & \\
\hline
\end{tabular}

Table A6. One-way analysis of variance (ANOVA) of dry matter contents for females at $48 \mathrm{~h}$

\begin{tabular}{c|c|c|c|c|c}
\hline Source & df & SS & MS & F & P value \\
\hline Time & 2 & 21.03 & 10.513 & 9.34 & 0.006 \\
Error & 9 & 10.13 & 1.125 & & \\
Total & 11 & 31.15 & & & \\
\hline
\end{tabular}

Table A7. One-way analysis of variance (ANOVA) of dry matter contents for females at $96 \mathrm{~h}$

\begin{tabular}{c|c|c|c|c|c}
\hline Source & df & SS & MS & F & P value \\
\hline Time & 2 & 58.680 & 29.3400 & 44.24 & 0.000 \\
Error & 9 & 5.969 & 0.6632 & & \\
Total & 11 & 64.649 & & & \\
\hline
\end{tabular}

Table A8. One-way analysis of variance (ANOVA) of dry matter contents for males at $48 \mathrm{~h}$

\begin{tabular}{c|c|c|c|c|c}
\hline Source & df & SS & MS & F & P value \\
\hline Concentration & 2 & 21.15 & 10.576 & 6.45 & 0.018 \\
Error & 9 & 14.75 & 1.639 & & \\
Total & 11 & 35.90 & & & \\
\hline
\end{tabular}

Table A9. One-way analysis of variance (ANOVA) of dry matter contents for males at $96 \mathrm{~h}$

\begin{tabular}{c|c|c|c|c|c}
\hline Source & df & SS & MS & F & P value \\
\hline Concentration & 2 & 65.44 & 32.722 & 26.58 & 0.000 \\
Error & 9 & 11.08 & 1.231 & & \\
Total & 11 & 76.52 & & & \\
\hline
\end{tabular}

Table A10. Three-way analysis of variance (ANOVA) of dry matter contents

\begin{tabular}{c|c|c|c|c|c}
\hline Source & df & SS & MS & F & P value \\
\hline Concentration & 2 & 100.709 & 50.3543 & 47.36 & 0.000 \\
Time & 2 & 130.981 & 65.4905 & 61.59 & 0.000 \\
Sex & 1 & 77.439 & 77.4390 & 72.83 & 0.000 \\
Error & 54 & 57.419 & 1.0633 & & \\
Total & 71 & 432.197 & & & \\
\hline
\end{tabular}


Table A11. One-way analysis of variance (ANOVA) of ash contents for females at $48 \mathrm{~h}$

\begin{tabular}{c|c|c|c|c|c}
\hline Source & df & SS & MS & F & P value \\
\hline Concentration & 2 & 9.881 & 4.9406 & 19.82 & 0.001 \\
Error & 9 & 2.243 & 0.2493 & & \\
Total & 11 & 12.125 & & & \\
\hline
\end{tabular}

Table A12. One-way analysis of variance (ANOVA) of ash contents for females at $96 \mathrm{~h}$

\begin{tabular}{c|c|c|c|c|c}
\hline Source & df & SS & MS & F & P value \\
\hline Concentration & 2 & 13.388 & 6.6938 & 34.57 & 0.000 \\
Error & 9 & 1.742 & 0.1936 & & \\
Total & 11 & 15.130 & & & \\
\hline
\end{tabular}

Table A13. One-way analysis of variance (ANOVA) of ash contents for males at $48 \mathrm{~h}$

\begin{tabular}{c|c|c|c|c|c}
\hline Source & df & SS & MS & F & P value \\
\hline Concentration & 2 & 7.797 & 3.8985 & 19.62 & 0.001 \\
Error & 9 & 1.788 & 0.1987 & & \\
Total & 11 & 9.585 & & & \\
\hline
\end{tabular}

Table A14. One-way analysis of variance (ANOVA) of ash contents for males at $96 \mathrm{~h}$

\begin{tabular}{c|c|c|c|c|c}
\hline Source & df & SS & MS & F & P value \\
\hline Concentration & 2 & 12.453 & 6.2264 & 32.64 & 0.000 \\
Error & 9 & 1.717 & 0.1908 & & \\
Total & 11 & 14.170 & & & \\
\hline
\end{tabular}

Table A15. Three-way analysis of variance (ANOVA) of ash contents

\begin{tabular}{c|c|c|c|c|c}
\hline Source & df & SS & MS & F & P value \\
\hline Concentration & 2 & 28.518 & 14.2588 & 60.98 & 0.000 \\
Time & 2 & 32.972 & 16.4858 & 70.50 & 0.000 \\
Sex & 1 & 15.522 & 15.5217 & 66.38 & 0.000 \\
Error & 54 & 12.628 & 0.2338 & & \\
Total & 71 & 104.814 & & & \\
\hline
\end{tabular}

Table A16. One-way analysis of variance (ANOVA) of fat contents for females at $48 \mathrm{~h}$

\begin{tabular}{c|c|c|c|c|c}
\hline Source & df & SS & MS & F & P value \\
\hline Concentration & 2 & 0.12740 & 0.063700 & 11.37 & 0.003 \\
Error & 9 & 0.05040 & 0.005600 & & \\
Total & 11 & 0.17780 & & & \\
\hline
\end{tabular}


Table A17. One-way analysis of variance (ANOVA) of fat contents for females at $96 \mathrm{~h}$

\begin{tabular}{c|c|c|c|c|c}
\hline Source & df & SS & MS & F & P value \\
\hline Concentration & 2 & 0.63112 & 0.315558 & 91.17 & 0.000 \\
Error & 9 & 0.03115 & 0.003461 & & \\
Total & 11 & 0.66227 & & & \\
\hline
\end{tabular}

Table A18. One-way analysis of variance (ANOVA) of fat contents for males at $48 \mathrm{~h}$

\begin{tabular}{c|c|c|c|c|c}
\hline Source & df & SS & MS & F & P value \\
\hline Concentration & 2 & 0.07052 & 0.035258 & 24.84 & 0.000 \\
Error & 9 & 0.01278 & 0.001419 & & \\
Total & 11 & 0.08329 & & & \\
\hline
\end{tabular}

Table A19. One-way analysis of variance (ANOVA) of fat contents for males at $96 \mathrm{~h}$

\begin{tabular}{c|c|c|c|c|c}
\hline Source & df & SS & MS & F & P value \\
\hline Concentration & 2 & 0.91805 & 0.459025 & 83.33 & 0.000 \\
Error & 9 & 0.04958 & 0.005508 & & \\
Total & 11 & 0.96763 & & & \\
\hline
\end{tabular}

Table A20. Three-way analysis of variance (ANOVA) of fat contents

\begin{tabular}{c|c|c|c|c|c}
\hline Source & df & SS & MS & F & P value \\
\hline Concentration & 2 & 0.91301 & 0.45650 & 130.50 & 0.000 \\
Time & 2 & 1.94311 & 0.97155 & 277.73 & 0.000 \\
Sex & 1 & 4.70222 & 4.70222 & 1344.20 & 0.000 \\
Error & 54 & 0.18890 & 0.00350 & & \\
Total & 71 & 8.58500 & & & \\
\hline
\end{tabular}

Table A21. One-way analysis of variance (ANOVA) of Ca contents for females at $48 \mathrm{~h}$

\begin{tabular}{c|c|c|c|c|c}
\hline Source & df & SS & MS & F & P value \\
\hline Concentration & 2 & 156452 & 78226.0 & 49667.29 & 0.000 \\
Error & 6 & 9 & 1.6 & & \\
Total & 8 & 156461 & & & \\
\hline
\end{tabular}

Table A22. One-way analysis of variance (ANOVA) of Ca contents for females at $96 \mathrm{~h}$

\begin{tabular}{c|c|c|c|c|c}
\hline Source & df & SS & MS & F & P value \\
\hline Concentration & 2 & 173595 & 86797.6 & 13938.86 & 0.000 \\
Error & 6 & 37 & 6.2 & & \\
Total & 8 & 173633 & & & \\
\hline
\end{tabular}


Table A23. One-way analysis of variance (ANOVA) of Ca contents for males at $48 \mathrm{~h}$

\begin{tabular}{c|c|c|c|c|c}
\hline Source & df & SS & MS & F & P value \\
\hline Concentration & 2 & 8284.63 & 4142.32 & 823.03 & 0.000 \\
Error & 6 & 30.20 & 5.03 & & \\
Total & 8 & 8314.83 & & & \\
\hline
\end{tabular}

Table A24. One-way analysis of variance (ANOVA) of Ca contents for males at $96 \mathrm{~h}$

\begin{tabular}{c|c|c|c|c|c}
\hline Source & df & SS & MS & F & P value \\
\hline Concentration & 2 & 24391.6 & 12195.8 & 5624.86 & 0.000 \\
Error & 6 & 13.0 & 2.2 & & \\
Total & 8 & 24404.6 & & & \\
\hline
\end{tabular}

Table A25. Three-way analysis of variance (ANOVA) of Ca contents

\begin{tabular}{c|c|c|c|c|c}
\hline Source & df & SS & MS & F & P value \\
\hline Concentration & 2 & 185511 & 92755 & 14560.76 & 0.000 \\
Time & 2 & 185975 & 92988 & 14597.25 & 0.000 \\
Sex & 1 & 507217 & 507217 & 79623.14 & 0.000 \\
Error & 36 & 229 & 6 & & \\
Total & 53 & 1110808 & & & \\
\hline
\end{tabular}

Table A26. One-way analysis of variance (ANOVA) of Fe contents for females at $48 \mathrm{~h}$

\begin{tabular}{c|c|c|c|c|c}
\hline Source & df & SS & MS & F & P value \\
\hline Concentration & 2 & 2930.89 & 1465.44 & 182.74 & 0.000 \\
Error & 6 & 48.12 & 8.02 & & \\
Total & 8 & 2979.00 & & & \\
\hline
\end{tabular}

Table A27. One-way analysis of variance (ANOVA) of Fe contents for females at $96 \mathrm{~h}$

\begin{tabular}{c|c|c|c|c|c}
\hline Source & df & SS & MS & F & P value \\
\hline Concentration & 2 & 6437.73 & 3218.86 & 928.63 & 0.000 \\
Error & 6 & 20.80 & 3.47 & & \\
Total & 8 & 6458.53 & & & \\
\hline
\end{tabular}

Table A28. One-way analysis of variance (ANOVA) of Fe contents for males at $48 \mathrm{~h}$

\begin{tabular}{c|c|c|c|c|c}
\hline Source & df & SS & MS & F & P value \\
\hline Concentration & 2 & 28.30 & 14.151 & 7.42 & 0.024 \\
Error & 6 & 11.47 & 1.908 & & \\
Total & 8 & 39.75 & & & \\
\hline
\end{tabular}


Table A29. One-way analysis of variance (ANOVA) of Fe contents for males at $96 \mathrm{~h}$

\begin{tabular}{c|c|c|c|c|c}
\hline Source & df & SS & MS & F & P value \\
\hline Concentration & 2 & 377.60 & 188.802 & 100.77 & 0.000 \\
Error & 6 & 11.24 & 1.874 & & \\
Total & 8 & 388.85 & & & \\
\hline
\end{tabular}

Table A30. Three-way analysis of variance (ANOVA) of Fe contents

\begin{tabular}{c|c|c|c|c|c}
\hline Source & df & SS & MS & F & P value \\
\hline Concentration & 2 & 3959.3 & 1979.7 & 325.15 & 0.000 \\
Time & 2 & 6045.8 & 3022.9 & 496.49 & 0.000 \\
Sex & 1 & 50683.5 & 50683.5 & 8324.47 & 0.000 \\
Error & 36 & 219.2 & 6.1 & & \\
Total & 53 & 68488.0 & & & \\
\hline
\end{tabular}

Table A31. One-way analysis of variance (ANOVA) of Zn contents for females at $48 \mathrm{~h}$

\begin{tabular}{c|c|c|c|c|c}
\hline Source & df & SS & MS & F & P value \\
\hline Concentration & 2 & 607.183 & 303.592 & 954.29 & 0.000 \\
Error & 6 & 1.909 & 0.318 & & \\
Total & 8 & 609.092 & & & \\
\hline
\end{tabular}

Table A32. One-way analysis of variance (ANOVA) of Zn contents for females at $96 \mathrm{~h}$

\begin{tabular}{c|c|c|c|c|c}
\hline Source & df & SS & MS & F & P value \\
\hline Concentration & 2 & 2144.77 & 1072.39 & 1636.34 & 0.000 \\
Error & 6 & 3.93 & 0.66 & & \\
Total & 8 & 2148.70 & & & \\
\hline
\end{tabular}

Table A33. One-way analysis of variance (ANOVA) of Zn contents for males at $48 \mathrm{~h}$

\begin{tabular}{c|c|c|c|c|c}
\hline Source & df & SS & MS & F & P value \\
\hline Concentration & 2 & 1457.19 & 728.597 & 208.19 & 0.000 \\
Error & 6 & 21.00 & 3.500 & & \\
Total & 8 & 1478.19 & & & \\
\hline
\end{tabular}

Table A34. One-way analysis of variance (ANOVA) of Zn contents for males at $96 \mathrm{~h}$

\begin{tabular}{c|c|c|c|c|c}
\hline Source & df & SS & MS & F & P value \\
\hline Concentration & 2 & 2899.01 & 1449.51 & 7025.45 & 0.000 \\
Error & 6 & 1.24 & 0.21 & & \\
Total & 8 & 2900.25 & & & \\
\hline
\end{tabular}


Table A35. Three-way analysis of variance (ANOVA) of Zn contents

\begin{tabular}{c|c|c|c|c|c}
\hline Source & df & SS & MS & F & P value \\
\hline Concentration & 2 & 4175.1 & 2087.57 & 2074.06 & 0.000 \\
Time & 2 & 4972.4 & 2486.18 & 2470.09 & 0.000 \\
Sex & 1 & 509.6 & 509.56 & 506.26 & 0.000 \\
Error & 36 & 36.2 & 1.01 & & \\
Total & 53 & 12662.3 & & & \\
\hline
\end{tabular}

Table A36. One-way analysis of variance (ANOVA) of Cd contents for females at $48 \mathrm{~h}$

\begin{tabular}{c|c|c|c|c|c}
\hline Source & df & SS & MS & F & P value \\
\hline Concentration & 2 & 398.764 & 199.382 & 2811.72 & 0.000 \\
Error & 6 & 0.425 & 0.071 & & \\
Total & 8 & 399.189 & & & \\
\hline
\end{tabular}

Table A37. One-way analysis of variance (ANOVA) of Cd contents for females at $96 \mathrm{~h}$

\begin{tabular}{c|c|c|c|c|c}
\hline Source & df & SS & MS & F & P value \\
\hline Concentration & 2 & 428.030 & 214.015 & 352.97 & 0.000 \\
Error & 6 & 3.638 & 0.606 & & \\
Total & 8 & 431.668 & & & \\
\hline
\end{tabular}

Table A38. One-way analysis of variance (ANOVA) of Cd contents for males at $48 \mathrm{~h}$

\begin{tabular}{c|c|c|c|c|c}
\hline Source & df & SS & MS & F & P value \\
\hline Concentration & 2 & 151.840 & 75.9201 & 126.27 & 0.000 \\
Error & 6 & 3.608 & 0.6013 & & \\
Total & 8 & 155.448 & & & \\
\hline
\end{tabular}

Table A39. One-way analysis of variance (ANOVA) of Cd contents for males at $96 \mathrm{~h}$

\begin{tabular}{c|c|c|c|c|c}
\hline Source & df & SS & MS & F & P value \\
\hline Concentration & 2 & 189.553 & 94.7763 & 206.78 & 0.000 \\
Error & 6 & 2.750 & 0.4583 & & \\
Total & 8 & 192.303 & & & \\
\hline
\end{tabular}

Table A40. Three-way analysis of variance (ANOVA) of Cd contents

\begin{tabular}{c|c|c|c|c|c}
\hline Source & df & SS & MS & F & P value \\
\hline Concentration & 2 & 697.70 & 348.850 & 770.06 & 0.000 \\
Time & 2 & 577.08 & 288.541 & 636.93 & 0.000 \\
Sex & 1 & 177.02 & 177.018 & 390.76 & 0.000 \\
Error & 36 & 16.31 & 0.453 & & \\
Total & 53 & 2016.23 & & & \\
\hline
\end{tabular}

